\title{
Stereoselective allylboration using $(B)-\gamma-$ alkoxyallyldiisopinocampheylboranes: highly selective reactions for organic synthesis
}

\author{
J. Subash Chandra and M. Venkat Ram Reddy* \\ 1039 University Drive, Departments of Chemistry and Biochemistry and of Pharmacy \\ Practice and Pharmaceutical Sciences, University of Minnesota Duluth, Duluth, MN 55812 \\ E-mail:vmereddy@d.umn.edu
}

Dedicated to the memory of Professor Herbert C. Brown

\begin{abstract}
This review describes the synthesis of novel alkoxyallylborane reagents derived from $\alpha$-pinene and their applications in stereoselective total synthesis of natural products. These reagents can be conveniently prepared and react readily with a wide variety of aldehydes and imines to provide the corresponding $\alpha$-alkoxy substituted homoallylic alcohols/amines respectively. The (Z)- $\gamma$-alkoxyallylborane reagents provide 1,2-syn $\alpha$-alkoxy homoallylic alcohols/amines while the corresponding $(E)$ - $\gamma$-alkoxyallylborane reagents furnish 1,2-anti products exclusively in very high enantioselectivities.
\end{abstract}

Keywords: Allylboration, alkoxyallylboration, $\alpha$-pinene, diisopinocampheylborane, homoallylic alcohol, $\alpha$-alkoxy-homoallylic alcohols, 1,2-syn diols, protecting groups

\section{Contents}

1. Preparation of $(B)-(Z)-\gamma$-[alkoxyallyl]diisopinocampheylborane

2. Applications of $(B)-(Z)-\gamma-[$ methoxyallyl]diisopinocampheylborane

3. Applications of $(B)-(Z)-\gamma-[($ methoxymethoxy $)$ allyl $]$ diisopinocampheylborane

4. Applications of $(B)-(Z)-\gamma-[(2-m e t h o x y e t h o x y m e t h o x y) a l l y l]$ diisopinocampheylborane

5. Applications of $(B)-(Z)-\gamma-[(2$-trimethylsilylethoxymethoxy)allyl]diisopinocampheylborane

6. Applications of $(B)-(Z)-\gamma-[(4-m e t h o x y p h e n o x y)$ allyl]diisopinocampheylborane

7. Applications of $(B)-(Z)-\gamma-[(2$-tetrahydropyranyloxy)allyl $]$ diisopinocampheylborane

8. Preparation and applications of $(B)-(E)-\gamma-[$ methoxyallyl $]$ diisopinocampheylborane

9. Conclusions 


\section{Introduction}

Allylboration is an important $\mathrm{C}-\mathrm{C}$ bond forming reaction in organic chemistry. ${ }^{1}$ Reaction of "allyl"boranes $\mathbf{1}$ with aldehydes $\mathbf{2}$ is advantageous over many "allyl"metalations in terms of stereoselectivity because allylboration proceeds via a rigid six-membered boracyclic transition state 3 (Figure 1). Unlike several other metals that produce toxic metal byproducts, boron eventually gets converted to boric acid salts that are non-toxic and less cumbersome to dispose. There are theoretically five different points of substitution on the "allyl" borane $\mathbf{2}$ thereby making this reaction highly versatile in terms of obtaining a wide variety of complex products.



Figure 1. The scope of "allyl"boration.

Several chiral auxiliaries have been examined for the asymmetric allylboration of aldehydes/imines to prepare the optically pure homoallylic alcohols/amines in high ee and de. ${ }^{2}$ Hoffmann, Brown, Yamamoto, Roush, and others have made significant contributions in this area. Hoffmann pioneered the first asymmetric allyl and crotylborations utilizing a camphorderived auxiliary ${ }^{3}$ for both single and double diastereoselective asymmetric synthesis. ${ }^{4}$ Yamamoto and coworkers introduced tartrate esters as chiral auxiliaries for propargylboration and allenylboration of aldehydes to produce homoallenyl and homopropargylic alcohols respectively in very high ee. ${ }^{5}$ They demonstrated that the ee's of the alcohols depend on the sterics of the alkyl group in the tartrate ester. Ethyl and isopropyl tartrates lead to lower ee's, while sterically bulky groups such as cyclododecyl and 2,4-dimethylpentyl tartrates lead to higher ee's. ${ }^{6}$ Roush extended the use of isopropyl tartrate as a chiral auxiliary for allyl and crotylborations. ${ }^{7}$ Several other "allyl"boranes derived from chiral 1,2-diols 5-8, ${ }^{8}$ oxazaborolane $\mathbf{9},{ }^{9}$ and diazaborolane $\mathbf{1 0},{ }^{10}$ etc. have also been developed for the asymmetric allylboration of aldehydes/imines (Figure 2). 
<smiles>[R]C([R])=CCB1OC([PH2+])C(c2ccccc2)O1</smiles><smiles>[R]C([R])=CCB1O[C@H](CCCCC)[C@@H](CCCCCC)O1</smiles><smiles>[R]C([R])=CCB1OC2C3CC(C)(C3(C)C)C2(P)C1(C)C</smiles>

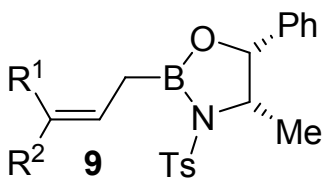

$\mathrm{R}^{1}=\mathrm{R}^{2}=\mathrm{H}$ $\mathrm{R}^{1}=\mathrm{H}, \mathrm{R}^{2}=\mathrm{CH}_{3}$

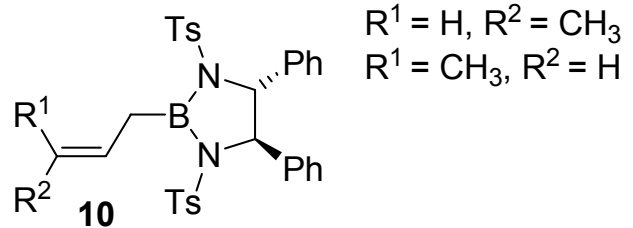

Figure 2. Various chiral auxiliary-based "allyl"boranes.

However, till date, the chiral allylborane derived from $\alpha$-pinene ( $B$ allyldiisopinocampheylborane 11), ${ }^{11}$ has proven to be the most effective in terms of high optical purity observed for a wide range of achiral and chiral aldehydes (Scheme 1). ${ }^{2 a, b}$ Several higher order "allyl"boranes derived from $\alpha$-pinene have been readily prepared either in situ or as isolable reagents. $^{2 \mathrm{a}, \mathrm{b}}$ All these reagents provide very good yields of the corresponding homoallylic alcohols/amines upon reaction with aldehydes/imines in excellent enantio- and diastereoselectivities.

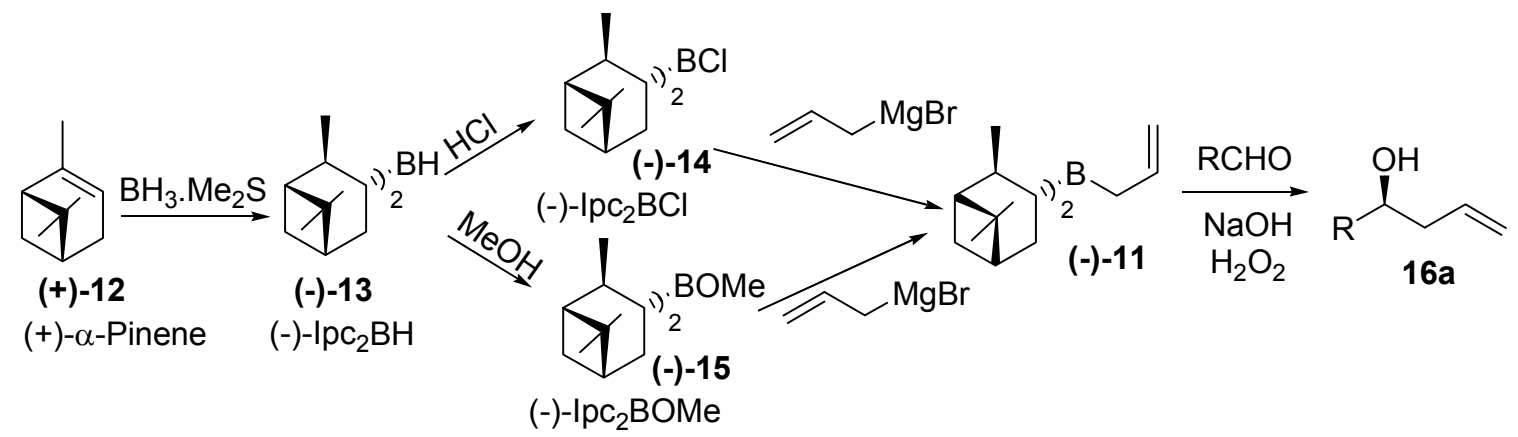

Scheme 1. Preparation and reactivity of $B$-allyldiisopinocampheylborane.

\section{Preparation of $(B)-(Z)-\gamma$-[alkoxyallyl]diisopinocampheylborane}

One of the several higher order allylboranes developed by Brown et. al. is (B)-(Z)- $\gamma-$ alkoxyallyldiisopinocampheylborane 20. This reagent is typically prepared and used in situ. Thus, the treatment of allylic ether $\mathbf{1 7}$ with a strong base such as sec-BuLi results in the formation of a $(Z)$-allylic anion 18. The exclusive $Z$-stereochemistry of the double bond is explained based on the coordination of lithium and oxygen resulting in a five membered cyclic transition state. ${ }^{12}$ Reaction of this anion 18 with Ipc $_{2}$ BOMe provides an "ate" complex 19, with a 
$(Z)$ geometric conformation of the olefin. Addition of a strong Lewis acid to the "ate" complex 19, releases the allylborane reagent $(B)-(Z)-(\gamma)$-alkoxyallyldiisopinocampheylborane 20. Reaction of aldehyde with $\mathbf{2 0}$ followed by oxidative workup using alkaline hydroperoxide yields the 1,2-syn $\alpha$-alkoxy homoallylic alcohol 22 in very high de and ee (Scheme 2).

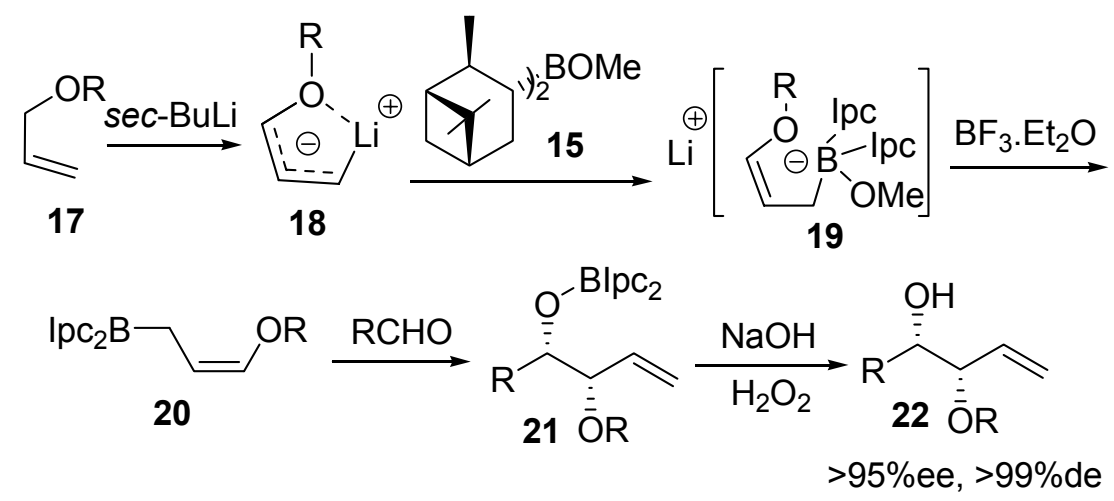

Scheme 2. Mechanism of alkoxyallylboration.

The reaction is highly reagent controlled and the enantiomer of the homoallylic alcohol is strictly governed by the antipode of $\mathrm{Ipc}_{2} \mathrm{BOMe}$ used. e.g. the reagent obtained from $(+)$ $\mathrm{Ipc}_{2} \mathrm{BOMe}$ always furnishes homoallylic alcohols with $\alpha$-configuration while the analogous reagent obtained from (-)- $\mathrm{Ipc}_{2} \mathrm{BOMe}$ provides alcohols with $\beta$-configuration (Scheme 3$){ }^{13}$ Thus the reaction of allylmethyl ether 17 with sec-butyl lithium followed by $(+)-\mathrm{Ipc}_{2} \mathrm{BOMe}_{3} \mathrm{BF}_{3}$. $\mathrm{Et}_{2} \mathrm{O}$, and acetaldehyde provided $(S, S)-22 \mathbf{a}$ in $92 \%$ ee. Similarly, acetaldehyde provided $90 \%$ ee of $(R, R)$-22a upon reaction with the alkoxyallylborane derived from (-)-Ipc ${ }_{2}$ BOMe. A variety of aldehydes such as propionaldehyde, isobutyraldehyde, benzaldehyde, and acrolein afforded the corresponding $(R, R)$ - or $(S, S)$ - alcohols in $89-92 \%$ ee depending on the antipode of the reagent used (Scheme 3). ${ }^{13}$

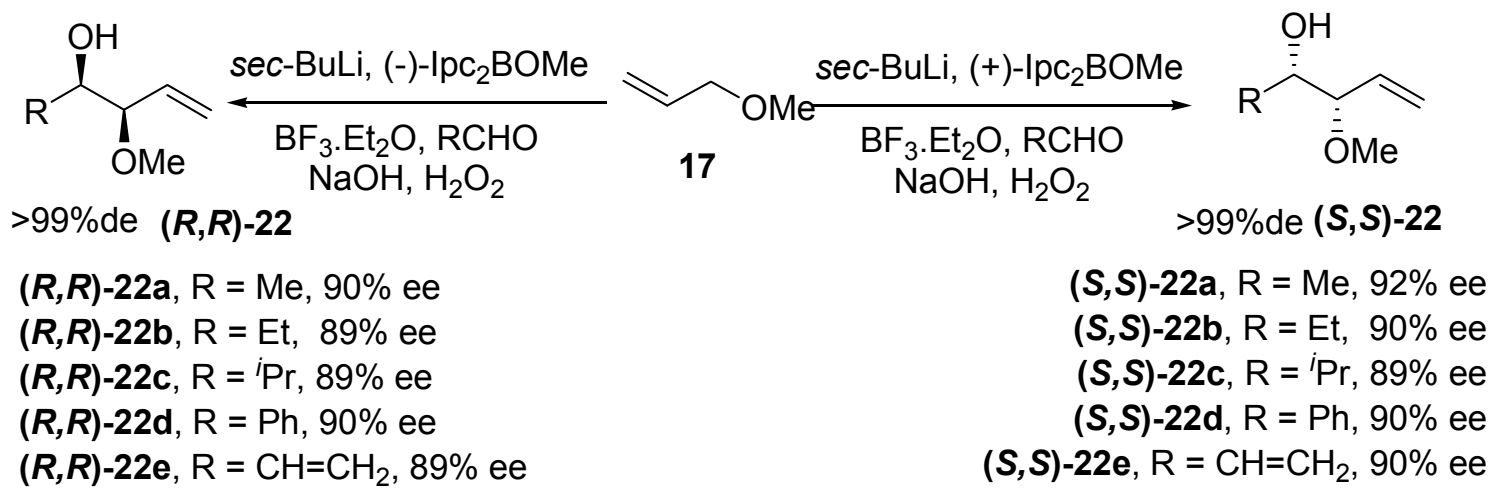

Scheme 3. Reagent controlled alkoxyallylboration. 
Although the alkoxyallylboration using allyl methyl ether is highly useful, the methoxy group in the product homoallylic alcohols requires strong reaction conditions and reagents for deprotection. This sometimes limits the application of the reagent especially in a molecule with sensitive functional/protecting groups. Accordingly, following the initial reports by Brown, several groups have modified the protecting groups on the reagent to obtain a variety of alkoxyallylborane reagents 20a-f (Figure 3). For example, the allylborane obtained by replacing the methoxy group (20a) with methoxymethyl (MOM) group (20b) results in the formation of $\alpha$ MOM substituted homoallylic alcohols, which could be further deprotected under mild reaction conditions to afford the 1,2-syn diols. The utility of several of these substituted reagents will be discussed in detail in the following sections.
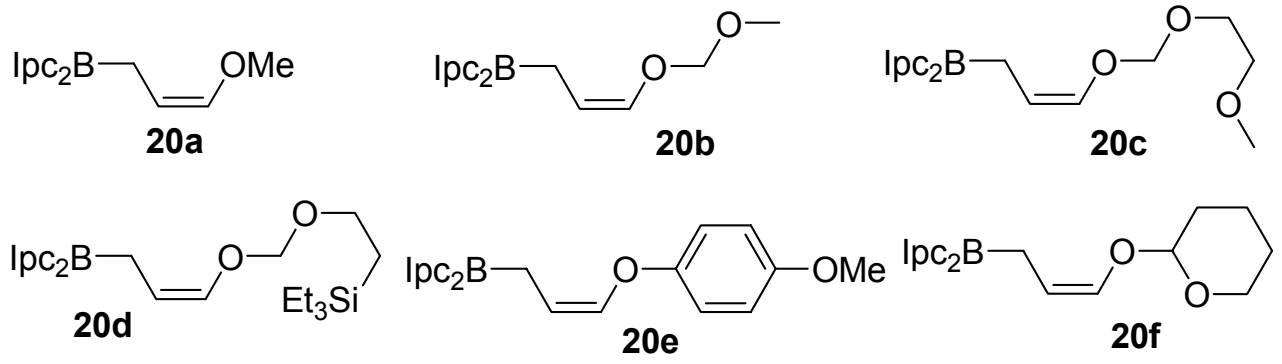

Figure 3. Various $(B)-\gamma$-alkoxyallyldiisopinocampheylboranes.

\section{Applications of $(B)-(Z)-\gamma$-[methoxyallyl]diisopinocampheylborane, 20a}

A formal synthesis of Carbomycin, a macrolide antibiotic, was achieved by Wuts and coworkers by utilizing the stereoselective alkoxyallylboration with 20a (Scheme 4). ${ }^{14}$ Thus the reaction of 3-benzyloxypropionaldehyde 23 with 20a afforded the homoallylic alcohol 24 in $>99 \%$ diastereoselectivity and $90 \%$ ee. Further transformations on $\mathbf{2 4}$ provided the subunit $\mathbf{2 5}$, which was earlier synthesized by Nicolaou during the synthesis of Carbomycin. ${ }^{15}$

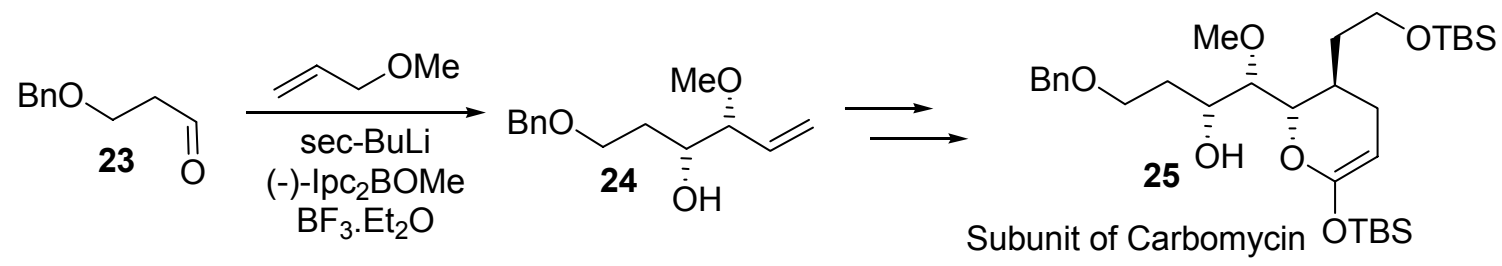

Scheme 4. Synthesis of a subunit of Carbomycin.

Several research groups have employed alkoxyallylboration as a key step in the synthesis of Herbimycin A, a potent antibiotic belonging to the class benzoquinoid ansamycin. ${ }^{16}$ Tatsuta reported the alkoxyallylboration of an $\alpha-\beta$-unsaturated aldehyde $\mathbf{2 6}$ with allylborane 20a 
providing the homoallylic alcohol 27, which was further converted to Herbimycin A 28 in several steps. ${ }^{16 a}$ Very recently, a similar type of aldehyde was also utilized by Cossy towards the synthesis of Herbimycin. ${ }^{16 \mathrm{c}}$ Panek and Carter utilized alkoxyallylboration of a highly advanced intermediate 29 to ascertain the $\mathrm{C}_{6}-\mathrm{C}_{7}$ stereochemistry in Herbimycin A (Scheme 5). ${ }^{16 \mathrm{~b}}$

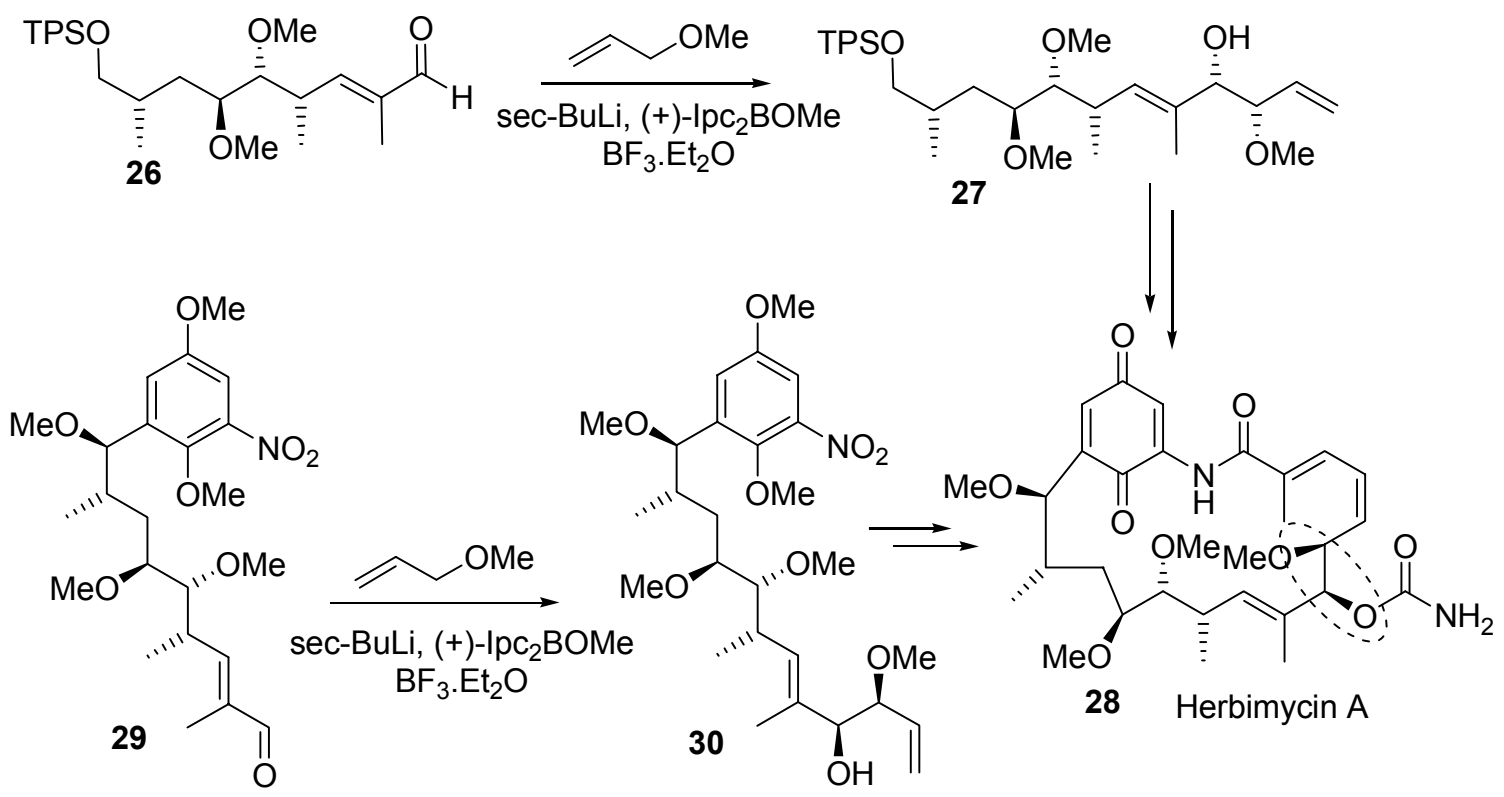

Scheme 5. Synthesis of Herbimycin.

Ganesh and Nicholas demonstrated that the cobalt carbonyl complexes of the acetylenic aldehydes 31 react with $\gamma$-methoxyallyldiisopinocampheylborane $\mathbf{2 0 a}$ to provide the homoallylic alcohols 32 in high yield and stereoselectivity (Scheme 6). ${ }^{17}$ It is important to note that the corresponding uncomplexed acetylenic aldehydes react under the same conditions and provide a very low yield of the product alcohols. It is relatively straight forward to carry out the deprotection of the cobalt carbonyl complexes using ceric ammonium nitrate to obtain the free homoallylic alcohols.<smiles></smiles>

31



$(\mathrm{OC})_{3} \mathrm{Co}-\mathrm{Co}(\mathrm{CO})_{3}$

32

Scheme 6. Alkoxyallylboration of $\mathrm{CO}_{2}(\mathrm{CO})_{6}$ complexes of acetylenic aldehydes.

Jung and coworkers developed a novel regio- and diastereoselective amination of allylic ethers using chlorosulfonyl isocyanate CSI. ${ }^{18}$ A wide variety of allylic ethers (e.g. 34) undergo 
this amination providing the corresponding acetamides 35. They were further able to extend this protocol for the synthesis of novel cytokine modulators namely cytoxazone and epi-cytoxazone 36 starting from the alkoxyallylboration of $p$-anisaldehyde 33 (Scheme 7). ${ }^{19}$

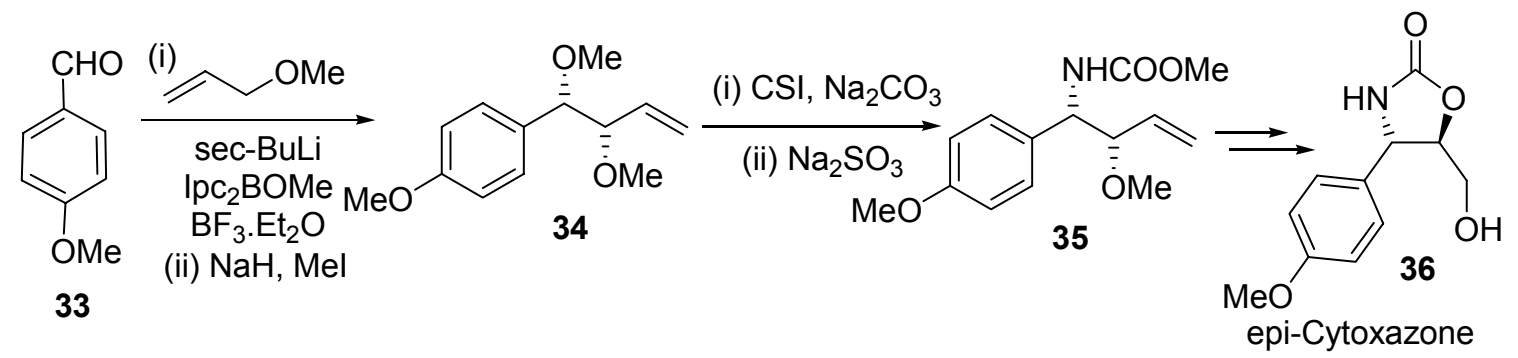

Scheme 7. Synthesis of epi-Cytoxazone.

There are very few reports of "allyl"boration of imines in the literature and recently Ramachandran et al. performed the alkoxyallylboration of imines as a key step for the synthesis of functionalized tetrahydropyridines. Partial reduction of nitriles with DiBAL-H provided the $N$-aluminoimines $\mathbf{3 7}$, which underwent alkoxyallylboration to afford the homoallylic amines $\mathbf{3 8}$ which were converted to the tetrahydropyridines 39 utilizing ring closing metathesis as a key step (Scheme 8). ${ }^{20}$
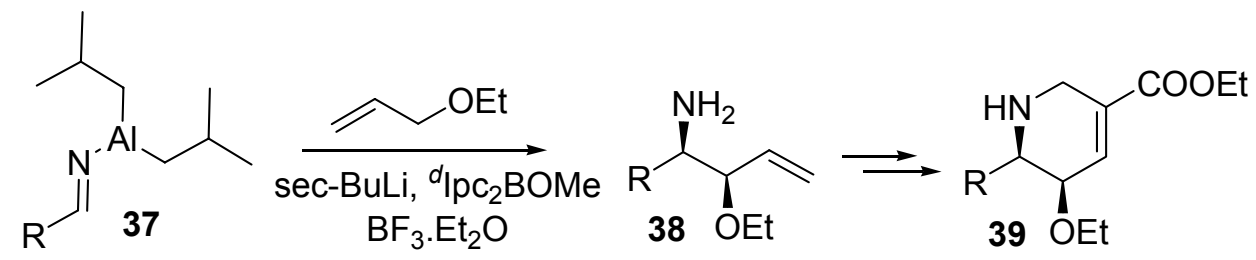

Scheme 8. Alkoxyallylboration of imines.

Kirschning and coworkers described the synthesis of proansamitocin 42, a key biosynthetic intermediate of a highly potent anti-tumor agent ansamitocin, utilizing the alkoxyallylboration of chiral aldehyde 40 with allylborane $20 a$ as a key step (Scheme 9). ${ }^{21}$

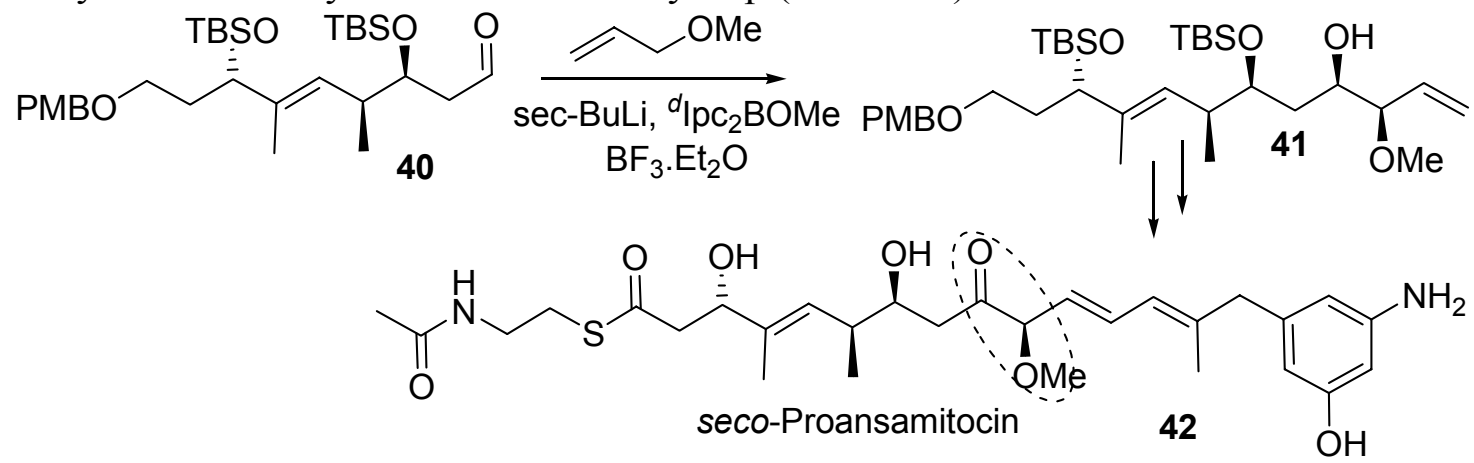

Scheme 9. Synthesis of seco-Proansamitocin. 


\section{Applications of $(B)-(Z)-\gamma-[($ methoxymethoxy $)$ allyl $]$ diisopinocampheyl borane, 20b}

Burgess and Henderson developed a novel approach for the synthesis of polyhydroxylated indolizidines 43 utilizing the homoallylic alcohols obtained from the alkoxyallylboration of aldehydes in four steps. They observed that the allylboranes obtained from both (+)- and (-)$\mathrm{Ipc}_{2} \mathrm{BOMe}$ react with the aldehyde $\mathbf{4 4}$ to provide the same enantiomer of the homoallylic alcohol 45 (Scheme 10). ${ }^{22}$ This is an interesting observation, as in most cases, $\alpha$-pinene based allyl reagents undergo reagent controlled additions to aldehydes, and incipient chirality of the substrate has no enantiocontrol over the product formation.

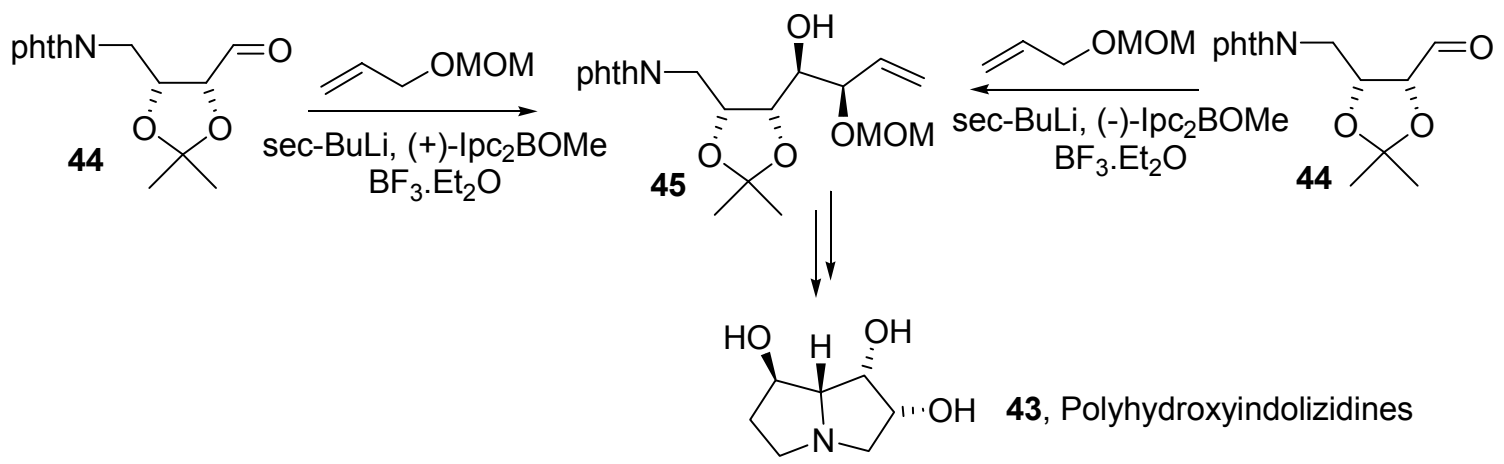

Scheme 10. Substrate controlled alkoxyallylboration.

Burgess and coworkers further synthesized several stereoisomers of castanospermine $\mathbf{4 8}$ utilizing alkoxyallylboration of aldehyde $\mathbf{4 6}$ as one of the key steps (Scheme 11). ${ }^{23}$
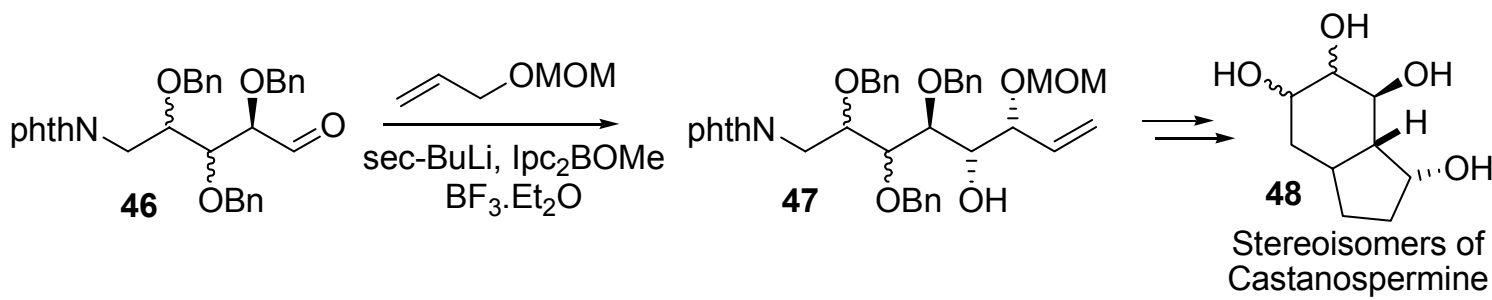

Scheme 11. Synthesis of Castanospermine stereoisomers.

Smith and Duan developed an $\mathrm{IBr}$ mediated diastereoselective electrophilic cyclization of carbonates derived from homoallylic alcohols $\mathbf{5 0}$ to afford $\alpha$-iodocarbonate 51 (Scheme 12) ${ }^{24}$ The product iodocarbonates are highly versatile intermediates in organic synthesis and can be utilized for the synthesis of epoxy alcohols, iodohydrins, diols, triols, cyclic carbonates etc. ${ }^{25}$ 

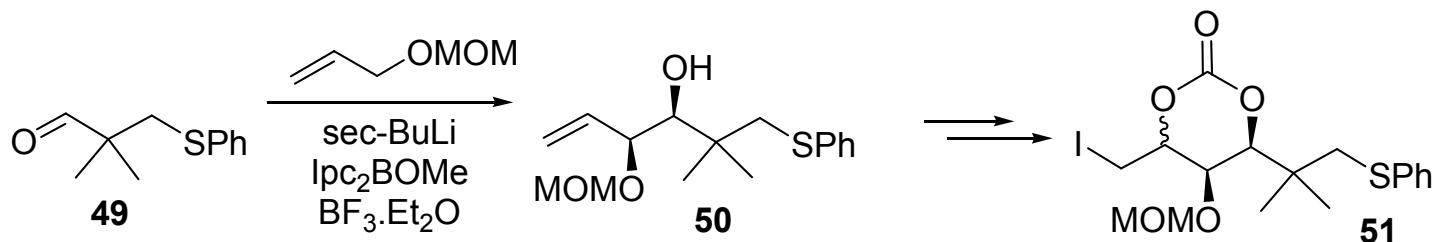

Scheme 12. Iodolactonization of homoallylic alcohols.

Alkoxyallylboration of an aldehyde $\mathbf{5 2}$ derived from arabinose, with $\gamma$ methoxymethoxyallyldiisopinocampheylborane $\mathbf{2 0 b}$ provided the homoallylic alcohol $\mathbf{5 3}$ in $80 \%$ yield and $>99 \%$ diastereoselectivity (Scheme 13). ${ }^{26}$ Jadhav et. al. were able to convert the octose derivative 53 into the polyhydroxyindolizidine 54 in seven further transformations. Several of these indolizidines such as castanospermine, swainsonine etc. exhibit potent anti-cancer, antiviral, and anti-AIDS activities. ${ }^{27}$

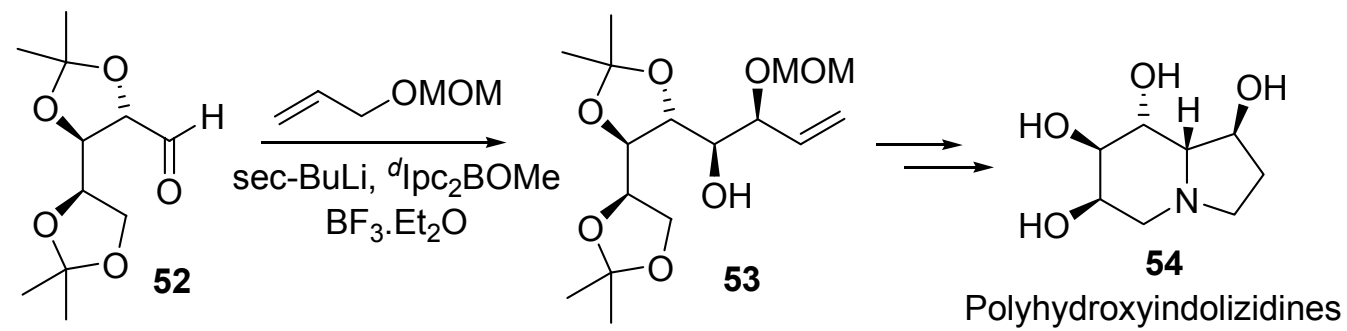

Scheme 13. Synthesis of polyhydroxyindolizidines.

Jadhav and coworkers were successful in synthesizing cyclic oxamides $\mathbf{5 7}$ as potent anti-HIV agents starting from the alkoxyallylboration of 3-phenylpropionaldehyde 55 with 20 b (Scheme 14)..$^{28}$

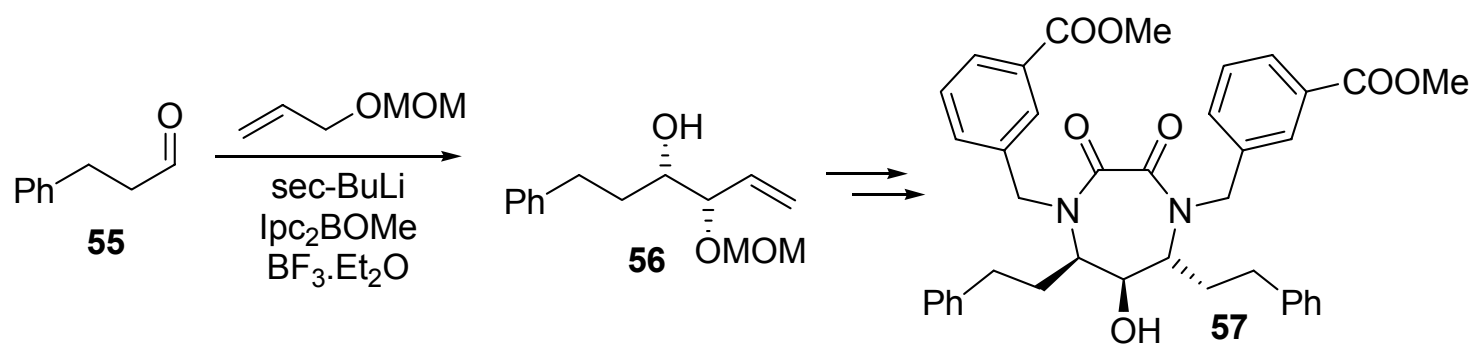

Cyclic oxamides as potent anti-HIV agents

Scheme 14. Synthesis of cyclic oxamides

Sutherland and Armstrong prepared a diverse set of C-trisaccharides as potential inhibitors for the cell surface proteins of the bacterium Helicobactor pylori utilizing alkoxyallylboration of 
a disachcharide aldehyde $\mathbf{5 8}$ with $\mathbf{2 0 b}$ yielding the homoallylic alcohol $\mathbf{5 9}$ which was further transformed into the C-trisaccharide in several steps (Scheme 15). ${ }^{29}$
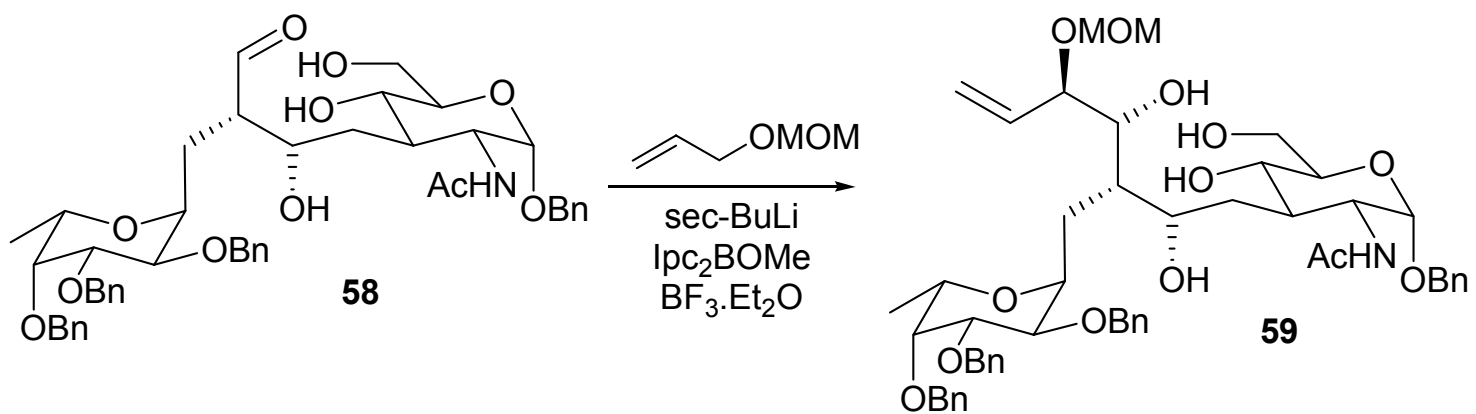

Scheme 15. Synthesis of C-trisaccharides.

Coleman and coworkers demonstrated the synthesis of a potent anti-tumor agent Azinomycin A starting with alkoxyallylboration of acrolein with allylborane reagent $\mathbf{2 0 b}$ (Scheme 16). ${ }^{30}$ The homoallylic alcohol $\mathbf{6 1}$, thus obtained was conveniently transformed into the fully functionalized aziridine core 62, of Azinomycin A.
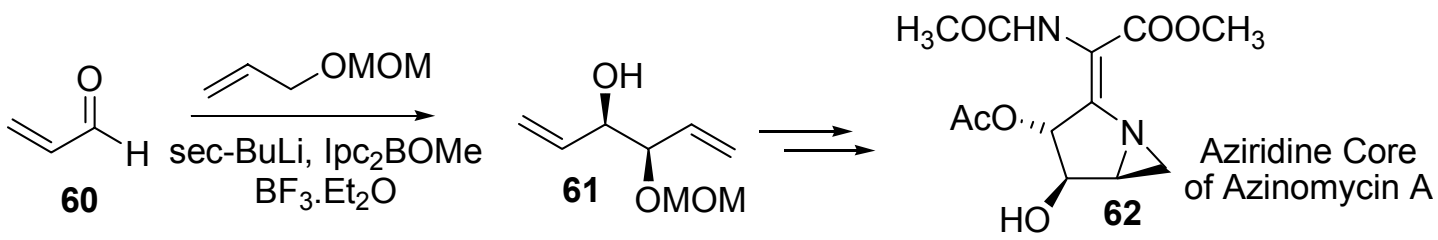

Scheme 16. Synthesis of Azinomycin A.

Barrett and coworkers synthesized restrictinol, the hydrolysis product of the anti-fungal natural product restricticin, utilizing the alkoxyallylboration of the $\alpha$-chiral aldehyde $\mathbf{6 3}$ derived from Roche's ester (Scheme 17). ${ }^{31}$ The homoallylic alcohol 64 thus obtained was further transformed into restrictinol.

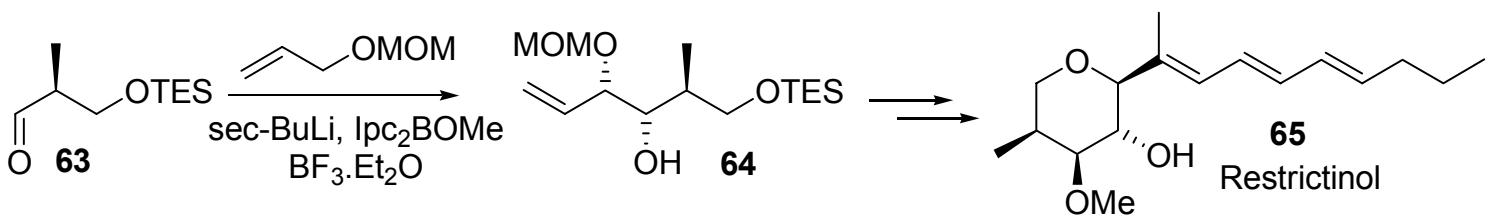

Scheme 17. Synthesis of Restrictinol.

Barrett's group also developed an efficient method for the formation of 1,2-oxasilines 68 starting from the homoallylic alcohols 67. Protection of alcohols 67 as vinylsilyl ethers, 
followed by ring closing metathesis afforded the oxasilines 68, which undergo fluoride mediated deprotection to provide the $\delta$-substituted homoallylic alcohols 69. Alkyl metals also react with the oxasilines $\mathbf{6 8}$ to afford the $\delta$-alkyl- $\delta$-silyl disubstituted homoallylic alcohols 70 (Scheme $18) .^{32}$

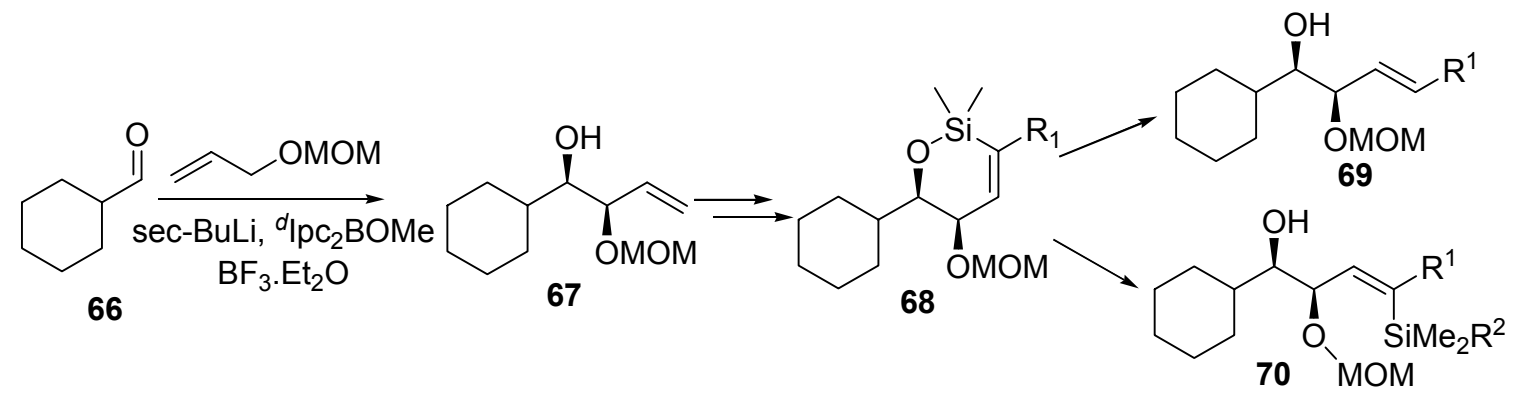

Scheme 18. Synthesis and applications of 1,2-oxasilines.

Barrett's group expanded the scope of the above protocol for the synthesis of glycosphingolipids as depicted in Scheme 19. ${ }^{33}$ Thus the alkoxyallylboration of the aldehyde 71 with allylborane 20b afforded the homoallylic alcohol $\mathbf{7 2}$ that upon silyl protection followed by ring closing metathesis afforded the oxasilines that were eventually transformed into the D, LGlucosylceramide 73 (Scheme 19).

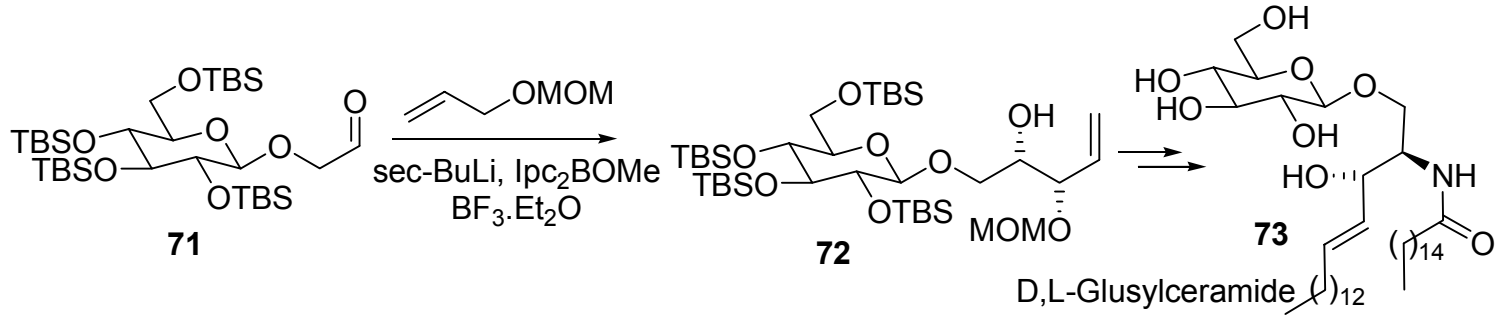

Scheme 19. Synthesis of glycosphingolipids.

Several others including Smith (Calyculin A, Scheme 20), ${ }^{34}$ Porco (Oximidines, Scheme 21), ${ }^{35}$ Gennari (Eleuthrobin, Scheme 22), ${ }^{36}$ DeBrabander (Peloruside, Scheme 23), ${ }^{37}$ Zhou $\left(\mathrm{C}_{1^{-}}\right.$ $\mathrm{C}_{16}$ subunit of Peloruside, Scheme 24$),{ }^{38}$ and Negishi $\left(\mathrm{C}_{1}-\mathrm{C}_{16}\right.$ side chain of Mycolactone, Scheme 25$)^{39}$ have employed alkoxyallylboration using reagent $\mathbf{2 0 b}$ en route to their stereoselective syntheses of several biologically important molecules. 


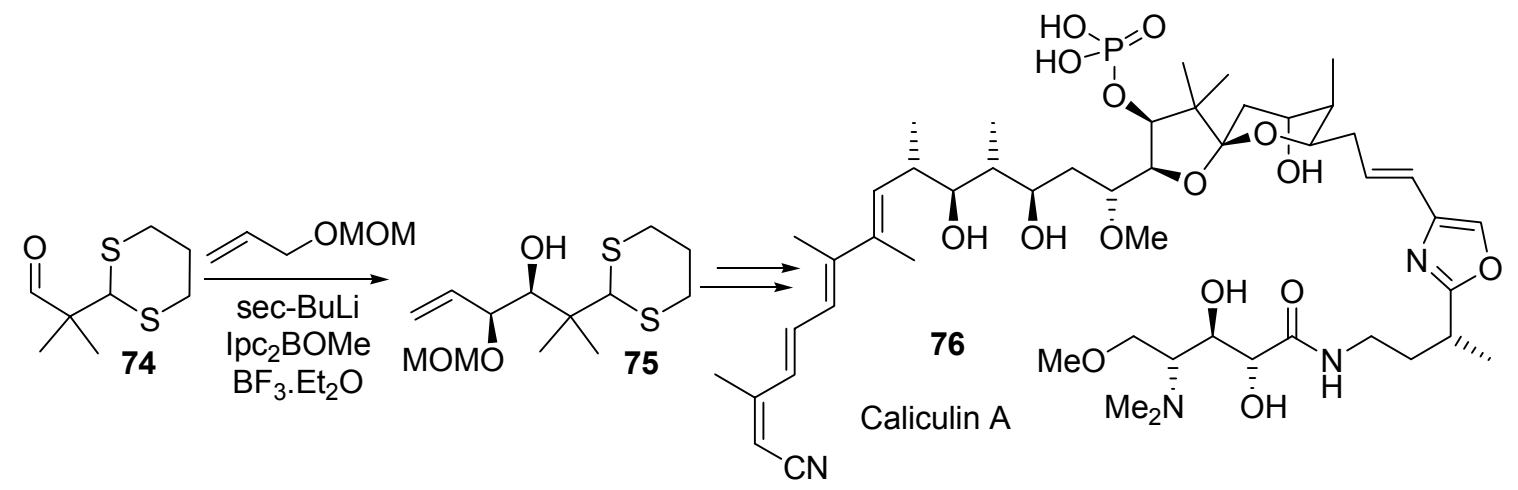

Scheme 20. Synthesis of Calyculin A.

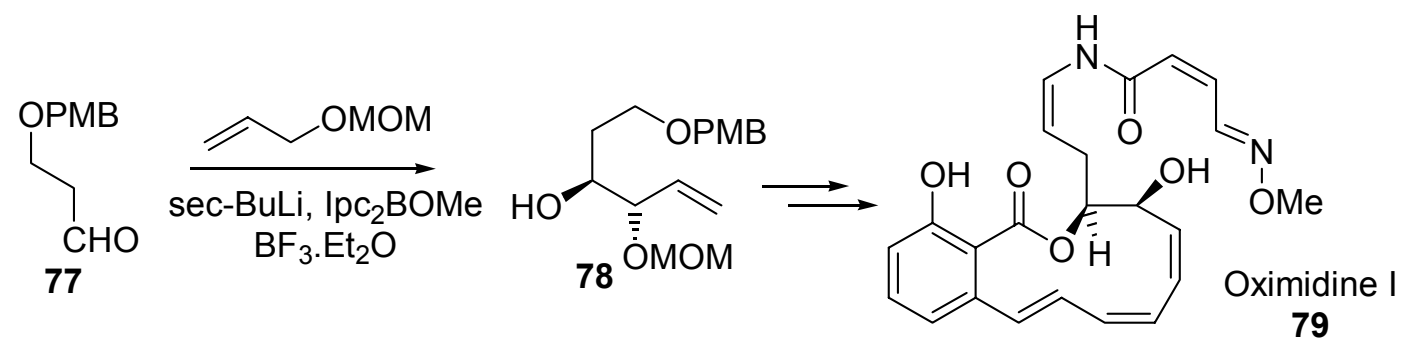

Scheme 21. Synthesis of Oximidine.

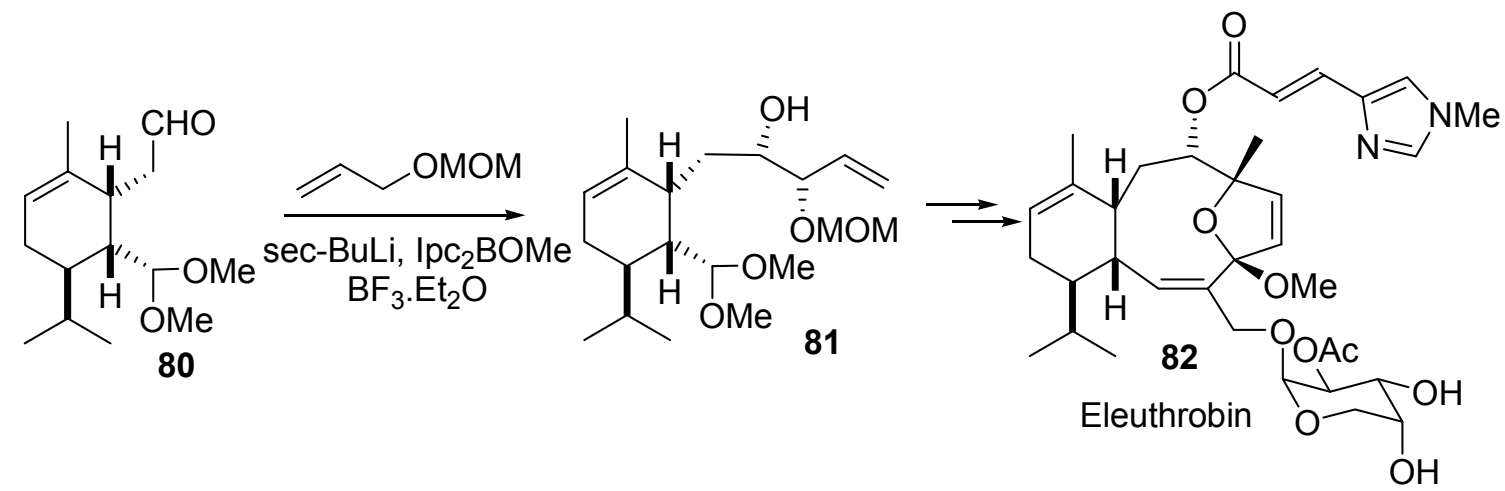

Scheme 22. Synthesis of Eleuthrobin.

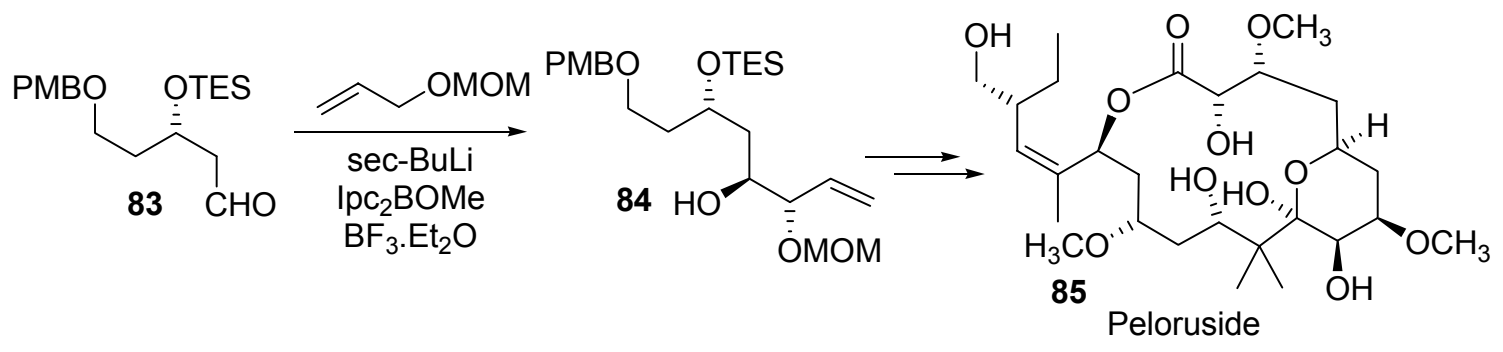

Scheme 23. Synthesis of Peloruside. 


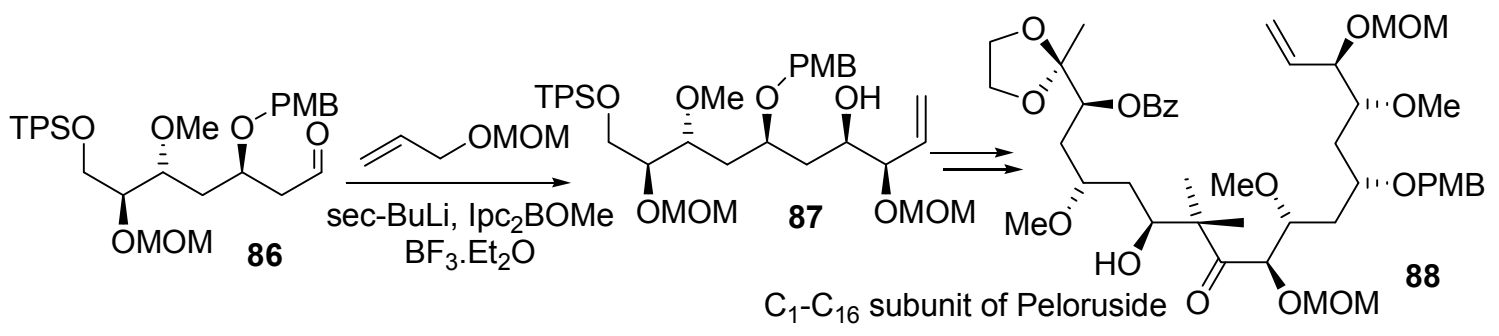

Scheme 24. Synthesis of $\mathrm{C}_{1}-\mathrm{C}_{16}$ subunit of Peloruside.

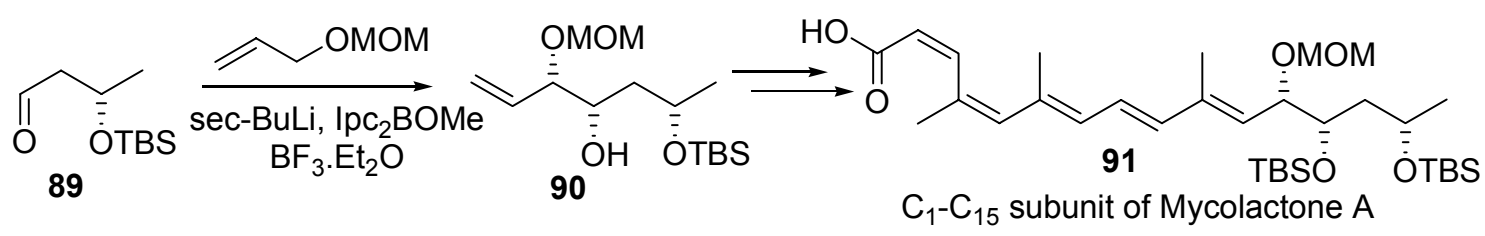

Scheme 25. Synthesis of $\mathrm{C}_{1}-\mathrm{C}_{15}$ side chain of Mycolactone A.

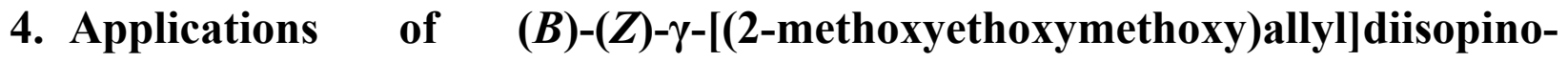 campheylborane, 20c}

Nicolaou described the total synthesis of Calicheamicinone 94 involving the alkoxyallylboration of a $\gamma$-lactol 92 with $B$ - $\gamma$-methoxyethoxymethoxyallyldiisopino campheylborane 21c as a key step (Scheme 26). ${ }^{40}$



92<smiles>C=C[C@@H](OC#N)[C@@H](O)CC1(CO)OCCO1</smiles>

93

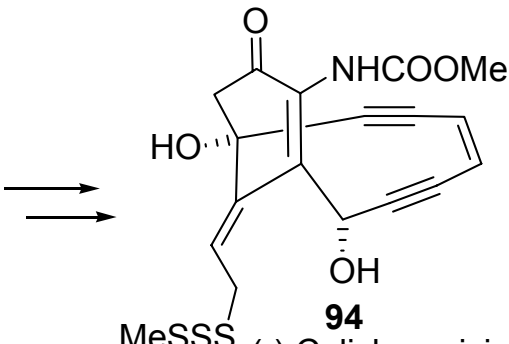

(-) Calicheamicinone

Scheme 26. Synthesis of (-)-Calicheamicinone.

Ramachandran et al. have demonstrated the utility of alkoxyallylboration with $B-\gamma-$ alkoxyallyldiisopinocampheylborane as the key step for the synthesis of several anti-tumor styryllactones such as goniodiol, epigoniodiol, and deoxygoniopypyrone. ${ }^{41}$ The alkoxyallylboration of benzaldehyde with 20c, provided $(S, S)$ - $\alpha$-alkoxyhomoallylic alcohol 96. The target lactones 97-100 were prepared in 6-7 steps starting from the homoallylic alcohol 96 via tandem allylboration and ring closing metathesis protocol (Scheme 27). 


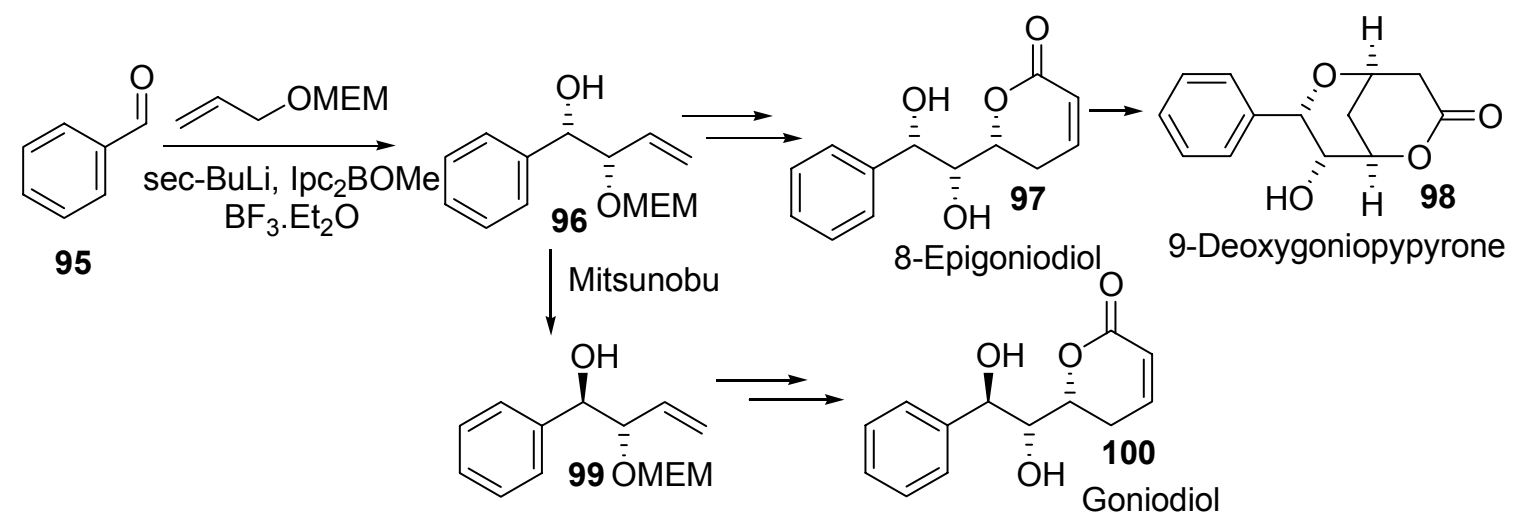

Scheme 27. Stereoselective synthesis of styryllactones.

The same group also achieved the stereoselective synthesis of $\mathrm{C}_{7}-\mathrm{C}_{21}$ subunit of potent anticancer agent Epothilone A, 103 starting from the $(S, S) \alpha$-alkoxyhomoallylic alcohol 102 derived from the alkoxyallylboration of acetaldehyde (Scheme 28). ${ }^{42}$

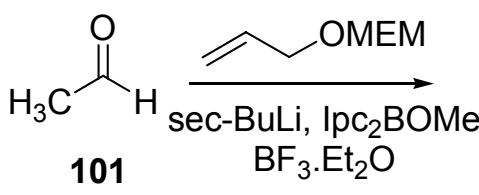

101<smiles>[M]O[C@H](C=C)[C@@H](C)O</smiles>

102

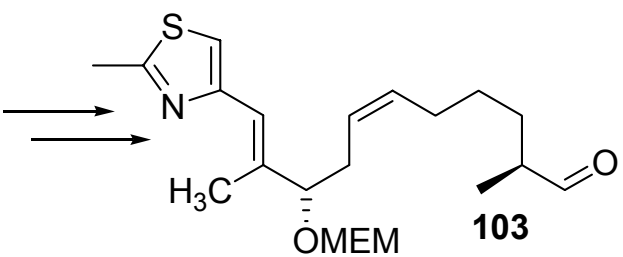

$\mathrm{C}_{7}-\mathrm{C}_{21}$ Subunit of Epothilone $\mathrm{A}$

Scheme 28. Synthesis of $\mathrm{C}_{7}-\mathrm{C}_{21}$ subunit of Epothilone.

They were further able to demonstrate the applicability of the $\alpha$-alkoxy homoallylic alcohols for the synthesis of $\beta$-hydroxy- $\delta$-lactones. ${ }^{43}$ The reaction of homoallylic alcohols 105 with acryloyl chloride followed by ring closing metathesis with Grubbs's II Generation catalyst 107 afforded $\alpha$-pyrones 108. Diastereoselective dihydroxylation of the double bond in $\mathbf{1 0 8}$ provided the 1,2-cis diol 109 that upon reaction with phenyl chlorothionoformate and $\mathrm{Bu}_{3} \mathrm{SnH}$ and $\mathrm{AIBN}$ yielded the $\alpha$-hydroxy- $\delta$-lactone 110 regioselectively (Scheme 29). This protocol was applied for the synthesis of $\mathrm{C}_{1}-\mathrm{C}_{8}$ and $\mathrm{C}_{15}-\mathrm{C}_{21}$ subunits of a potent anti-cancer agent Discodermolide. ${ }^{43}$ 


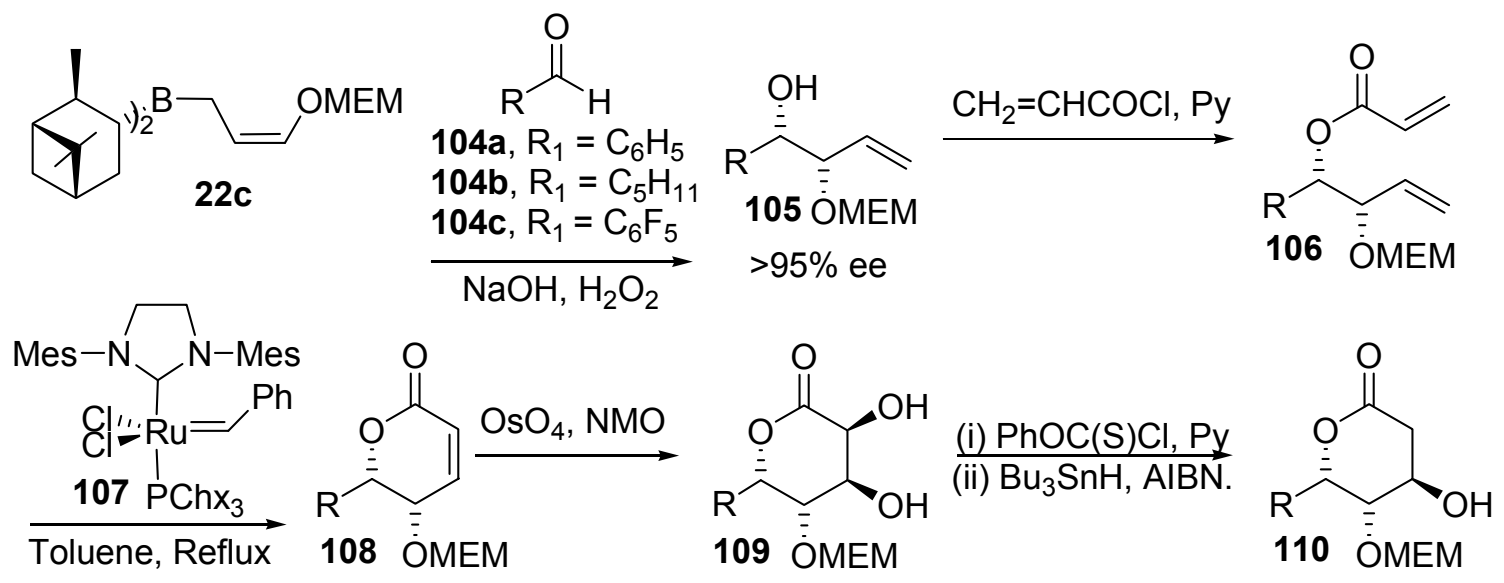

Scheme 29. Diastereoselective dihydroxylation and regioselective deoxygenation.

Oxidation of the $\alpha$-alkoxy alcohols 112 derived from alkoxyallylboration of aldehydes, afforded the $\alpha$-alkoxyketones that underwent diastereoselective chelation controlled nucleophilic addition with a variety of nucleophiles affording the homoallylic chiral tertiary alcohols $\mathbf{1 1 3}$. Further transformations on alcohol 113 yielded the $\mathrm{C}_{1}-\mathrm{C}_{11}$ subunit of Fostriecin (Scheme 30). ${ }^{44}$

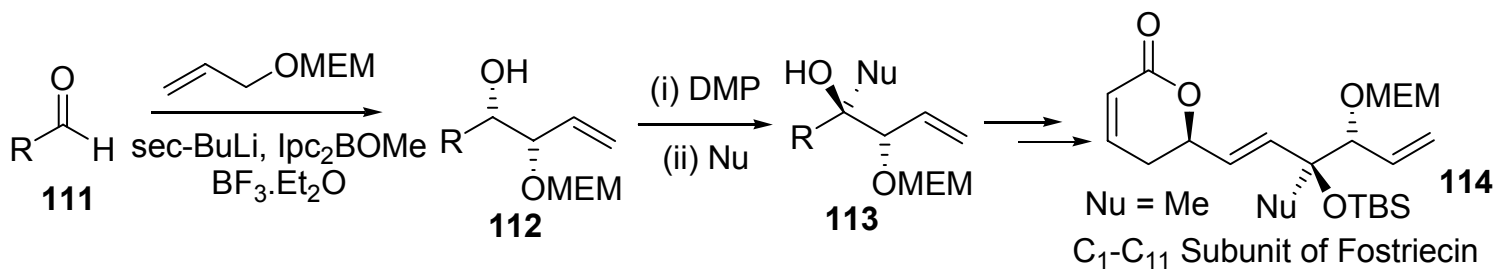

Scheme 30. Synthesis of $C_{1}-C_{11}$ subunit of Fostriecin.

Extension of alkoxyallylboration to perfluoroaldehydes, provided the fluoro-homoallylic alcohols $\mathbf{1 1 6}$ which were eventually converted to the fluorinated $\gamma$-lactones $\mathbf{1 1 7}$ and $\delta$-lactones 118 in 2-3 steps (Scheme 31). ${ }^{45}$ A trifluoromethyl analog of blastmycinolactol 121 was also synthesized starting the homoallylic alcohol $\mathbf{1 2 0}$ derived from alkoxyallylboration of trifluoroacetaldehyde 119 (Scheme 32 ). ${ }^{46}$

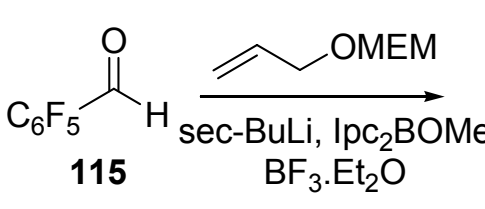<smiles>C1CCCCC1</smiles>

116

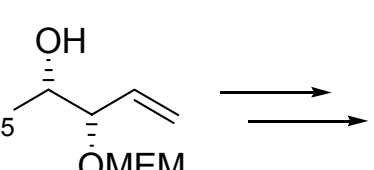

OMEM<smiles>O=C1C[C@H](O)[C@H](SC(F)(F)F)O1</smiles><smiles>O=C1CC[C@@H](O)[C@H](C(F)(F)F)O1</smiles>

Fluorinated $\gamma$, and $\delta$-lactones

Scheme 31. Synthesis of fluorinated $\gamma$-and $\delta$-lactones. 

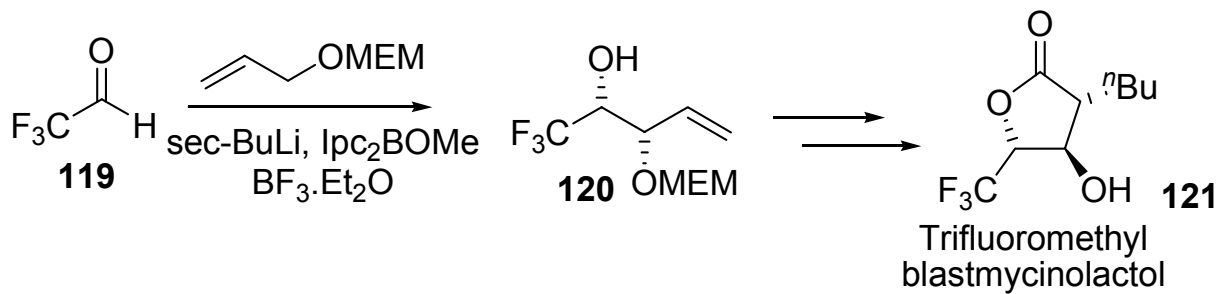

Scheme 32. Synthesis of fluorinated blastmycinolactol.

The same group utilized the homoallylic alcohols obtained by the alkoxyallylboration of $\alpha, \beta$ unsaturated aldehyde 122, for the synthesis of acetamides 124 via a [3,3]-sigmatropic Overman rearrangement ${ }^{47}$ (Scheme 33). ${ }^{48}$

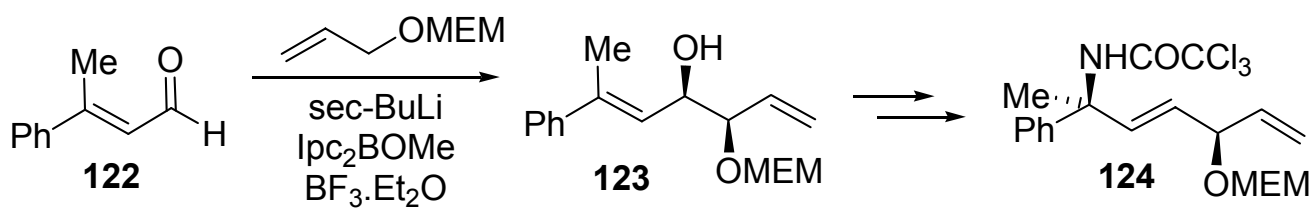

Scheme 33. Overman rearrangement of homoallylic alcohols.

Recently, Curran and coworkers utilized the alkoxyallylboration of $n$-tridecanal with both antipodes of $B$ - $\gamma$-alkoxyallyldiisopinocampheylborane for the synthesis of $(S, S)$ and $(R, R)$ 1,2syn $\alpha$-alkoxy homoallylic alcohols syn-126. ${ }^{49}$ Mitsunobu inversion of the corresponding alcohols afforded two anti alcohols anti-126. All these four diastereomers were later tagged to a fluorous PMB-bromide ${ }^{50}$ and were converted to (+)-Murisolin and fifteen other diastereomers in several steps (Scheme 34).



Scheme 34. Synthesis of Murisolin and its stereoisomer libraries.

\section{Applications of $(B)-(Z)-\gamma-[(2$-trimethylsilylethoxymethoxy $)$ allyl $]$ diisopinocampheylborane, $20 \mathrm{~d}$}

Barrett and coworkers demonstrated for the first time that silyl protecting groups could also be utilized for the alkoxyallylboration of aldehydes (Scheme 35). ${ }^{51}$ As is apparent, the SEM ether is 
sensitive to the Lewis acid $\left(\mathrm{BF}_{3} \cdot \mathrm{Et}_{2} \mathrm{O}\right)$, and hence they carried out the allylboration without the use of $\mathrm{BF}_{3} \cdot \mathrm{Et}_{2} \mathrm{O}$. The "ate" complex of the reagent $\mathbf{2 0 d}$ was equally reactive like the free "allyl"borane to provide the alcohol 129 that upon further transformations provided the $\mathrm{C}_{1}-\mathrm{C}_{25}$ subunit 130 of Calyculin A (Scheme 35).

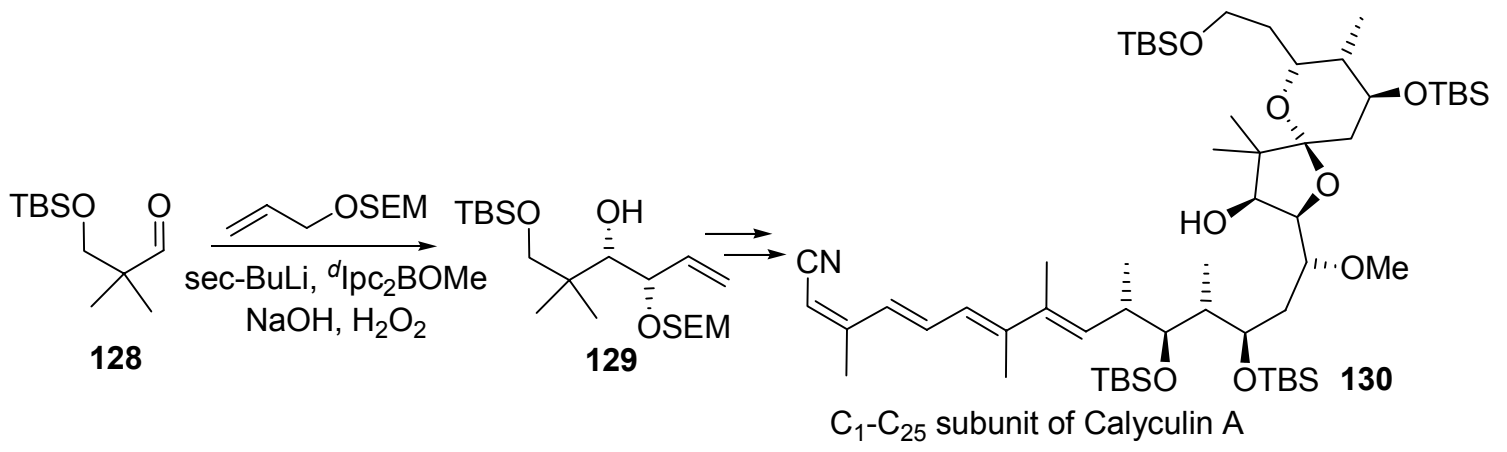

Scheme 35. Synthesis of $\mathrm{C}_{1}-\mathrm{C}_{25}$ subunit of Calyculin A.

Similarly, Roush (hydroxylamino sugar of Calicheamycin, Scheme 36), ${ }^{52}$ and Overman (Laurencin, Scheme 37$)^{53}$ also utilized the alkoxyallylboration of the corresponding aldehydes 131 and 134 with $B$ - $\gamma$-trimethylsilylethoxymethoxyallyldiisopinocampheyl-borane 20d as the main steps in their respective syntheses.



Scheme 36. Synthesis of hydroxylamino sugar of Calicheamicin.



Scheme 37. Synthesis of Laurencin. 


\section{Applications of $(B)-(Z)-\gamma-[(4-m e t h o x y p h e n o x y)$ allyl]diisopino- campheylborane (20e)}

Incorporation of an aryl moiety as the protecting group in the alkoxyallylborane, was achieved en route to the synthesis of styryllactones epigoniodiol 139 and goniodiol 141. As is evident, the two structures possess syn- and anti- 1,2-diol moieties respectively. The initial alkoxyallylboration of benzaldehyde with allylborane $20 \mathrm{e}$ led to the formation of the homoallylic alcohol 138. The judicious choice of PMP protecting group in the allylborane 20e was made, so as to utilize $p$-methoxyphenol as a nucleophile in the next step (Mitsunobu inversion) of alcohol $\mathbf{1 3 8}$ to bis aryl ether $\mathbf{1 4 0}$ (Scheme 38 ). ${ }^{41}$

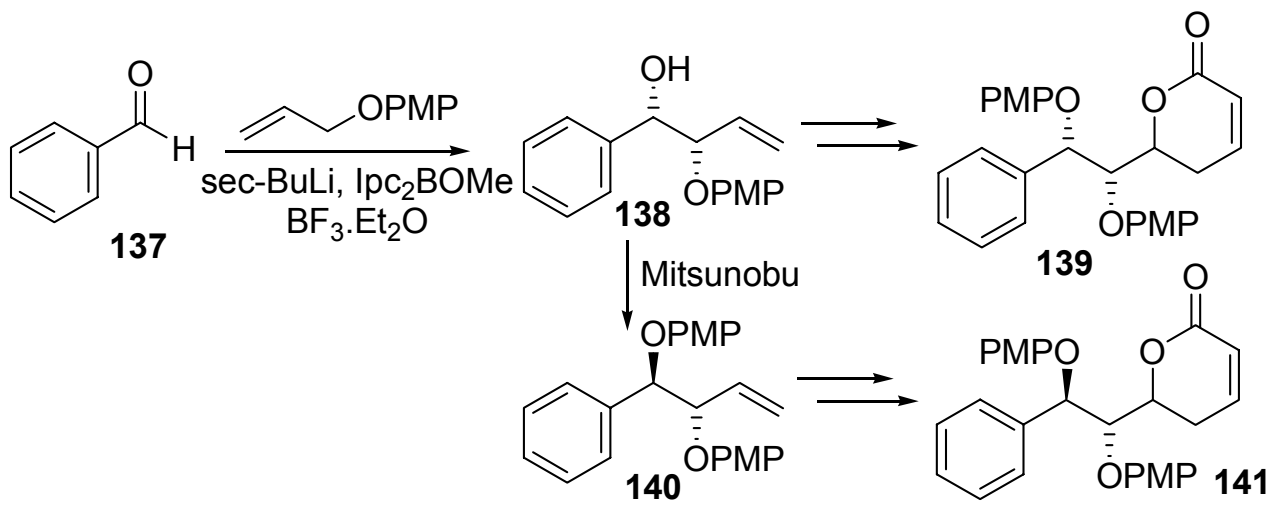

Scheme 38. Synthesis of styryllactones.

Gennari and workers utilized the reagent 20e for alkoxyallylboration of $\mathbf{1 4 2}$ en route to the synthesis of a key intermediate of eleuthrobin 144 (Scheme 39). ${ }^{36 c, 54}$
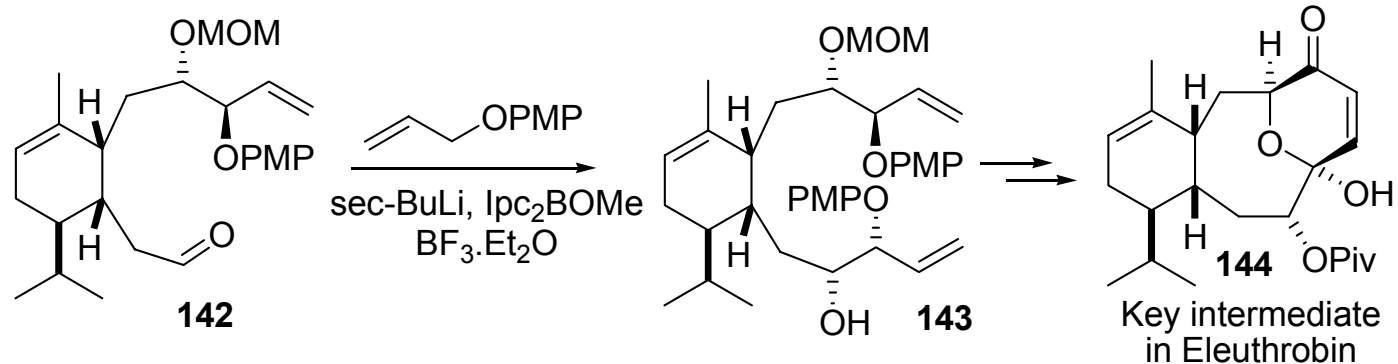

Scheme 39. Synthesis of the core of Eleuthrobin. 


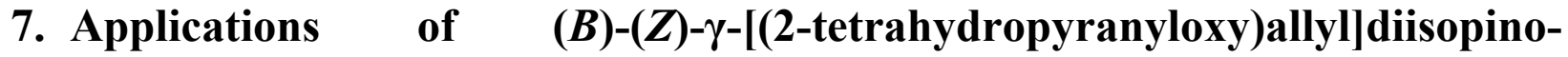 campheylborane (20f)}

Armstrong and Sutherlin demonstrated the use of tetrahydropyranyloxyallyldiisopino campheylborane 20f with a sugar based aldehyde 145 to obtain the alcohol 146 which was eventually converted to fused dihydropyranose oligosachcharides 147 (Scheme 40). ${ }^{55}$
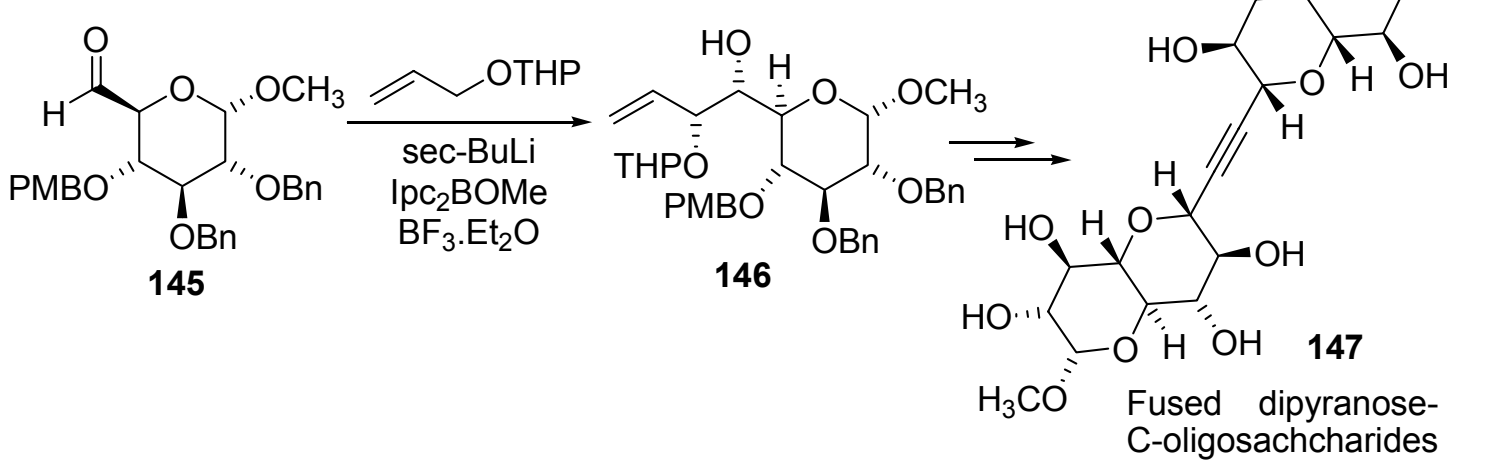

Scheme 40. Synthesis of $C$-oligosachcharides.

\section{Preparation and Applications of (B)-(E)- $\gamma$-Methoxyallyldiisopino campheylborane (149)}

Ganesh and Nicholas were successful in the synthesis of anti- $\beta$-alkoxyhomoallylic alcohols 150 via the alkoxyallylboration of cobalt complexed acetylenic aldehydes with the $E$ methoxyallyldiisopinocampheylborane (Scheme 41). ${ }^{56}$ The $(E)$ - alkoxyallylborane 149 was prepared utilizing a procedure by Hoffmann and coworkers involving the reduction of methoxy3-(phenylthio)propene 148 with potassium naphthalenide and subsequent treatment with $\mathrm{Ipc}_{2} \mathrm{BOMe}($ Scheme 41$){ }^{57}$

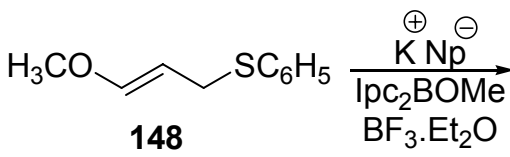

148
$\mathrm{H}_{3} \mathrm{CO}$

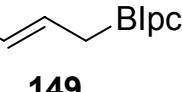

149<smiles>[R]C(C=O)C(=O)OCCOC(=O)[O-]</smiles>

$(\mathrm{OC})_{3} \mathrm{CO}-\mathrm{Co}(\mathrm{CO})_{3}$

150

Scheme 41. Synthesis of (E)- $\gamma$-alkoxyallyldiisopinocampheylborane. 


\section{Conclusions}

In conclusion, this review describes novel alkoxyallylboranes derived from $\alpha$-pinene and their applications in stereoselective total synthesis of natural products. These reagents upon reaction with a wide variety of aldehydes provide very high diastereo- and enantioselectivities for the product $\beta$-alkoxy-homoallylic alcohols. This account presents the convenient preparation and synthetic utility of these highly selective reagents for total synthesis of complex natural products. We believe that this review demonstrates the potential and robustness of the $\alpha$-pinene based alkoxyallylborane reagents and provides an impetus towards enhancing the applications of these highly selective reagents for organic synthesis.

\section{Acknowledgements}

We thank the Department of Chemistry and Biochemistry and the College of Pharmacy Duluth for the facilities and funding.

\section{References and Notes}

1. For reviews on allylation, see: (a) Hoffmann, R. W. Pure Appl. Chem. 1988, 60, 123. (b) Yamamoto, Y.; Asao, N. Chem. Rev. 1993, 93, 2207. (c) Roush, W. R. In Methods of Organic Chemistry (Houben-Weyl); Georg Thieme: Stuttgart, 1995; Vol. E 21, p 1410.

2. For reviews on boron allylations, see: (a) Ramachandran, P. V. Aldrichim. Acta 2002, 35, 23.

(b) Brown, H. C.; Ramachandran, P. V. J. Organomet. Chem. 1995, 500, 1. (c) Brown, H. C.; Ramachandran, P. V. In Advances in Asymmetric Synthesis; Hassner, A., Ed.; JAI: Greenwich, CT, 1995; Vol. 1, Chap. 5. (d) Brown, H. C.; Ramachandran, P. V. Pure Appl. Chem. 1994, 66, 201. (e) Brown, H. C.; Ramachandran, P. V. Pure Appl. Chem. 1991, 63, 307. Roush, W. R. In Comprehensive Organic Synthesis; Trost, B. M., Fleming, I., Eds.; Pergamon Press: Oxford, U.K., 1991; Vol. 2.

3. (a) Herold, T.; Schrott, U.; Hoffmann, R. W. Chem. Ber. 1981, 114, 359. (b) Hoffmann, R. W.; Herold, T. Chem. Ber. 1981, 114, 375.

4. (a) Hoffmann, R. W. Angew. Chem. Int. Ed. 1982, 21, 555. (b) Hoffmann, R. W. Angew. Chem. Int. Ed. 1987, 26, 489. (c) Hoffmann, R. W. Pure Appl. Chem. 1988, 60, 123. (d)

Hoffmann, R. W.; Neil, G.; Schlapbach, A. Pure Appl. Chem. 1990, 62, 1993.

5. Haruta, R.; Ishiguro, M.; Ikeda, N.; Yamamoto, H. J. Am. Chem. Soc. 1982, 104, 7667.

6. Ikeda, N.; Arai, I.; Yamamoto, H. J. Am. Chem. Soc. 1986, 108, 483.

7. (a) Roush, W. R.; Walts, A. E.; Hoong, L. K. J. Am. Chem. Soc. 1985, 107, 8186. (b) Roush, W. R.; Halterman, R. L. J. Am. Chem. Soc. 1986, 108, 294.

8. Ditrich, K.; Bube, T.; Strumer, R.; Hoffmann, R. W. Angew. Chem. Int. Ed. 1986, 25, 1028. 
9. Reetz, M. T.; Zierke, T. Chem. Ind. 1988, 663.

10. Corey, E. J.; Yu, C.-M.; Kim, S. S. J. Am. Chem. Soc. 1989, 111, 5495.

11. (a) Brown, H. C.; Jadhav, P. K. J. Org. Chem. 1984, 49, 4089. (b) Brown, H. C.; Jadhav, P. K. J. Am. Chem. Soc. 1983, 105, 2095.

12. (a) Evans, D. A.; Andrews, G. C.; Buckwalter, B. J. Am. Chem. Soc. 1974, 96, 5560; (b) Still, W. C.; Macdonald, T. L. J. Org. Chem. 1976, 41, 3620.

13. Brown, H. C.; Jadhav, P. K.; Bhat, K. S. J. Am. Chem. Soc. 1998, 110, 1588.

14. Wuts, P. G. M.; Bigelow, S. S. J. Org. Chem. 1988, 53, 5023.

15. Nicolaou, K. C.; Seitz, S. P.; Pavia, M. R.; J. Am. Chem. Soc. 1981, 103, 1222.

16. (a) Nakata, M.; Osumi, T.; Ueno, A.; Kimura, T.; Tamai, T.; Tatsuta, K. Tetrahedron Lett. 1991, 32, 6015. (b) Carter, K. D.; Panek, J. S. Org. Lett. 2004, 6, 55. (c) Canova, S.; Bellosta, V.; Bigot, A.; Mailliet, P.; Mignani, S.; Cossy, J. Org. Lett. 2007, 9, 145.

17. Ganesh, P.; Nichols, K. M. J. Org. Chem. 1993, 58, 5587.

18. Kim, J. D.; Zee, O. P.; Jung, Y. H. J. Org. Chem. 2003, 68, 3721.

19. (a) Kim, J. D.; Kim, I. S.; Hua, J. C.; Zee, O. P.; Jung, Y. H. Tetrahedron Lett. 2005, 46, 1079; (b) Kim, I. S.; Kim, J. D.; Ryu, C. B.; Zee, O. P.; Jung, Y. H. Tetrahedron 2006, 62, 9349.

20. Ramachandran, P. V.; Burghardt, T. V.; Berry, L. B. J. Org. Chem. 2005, 70, 7911.

21. Frenzel,T.; Brunjes, M.; Quitschalle,M.; Kirschning, A. Org. Lett. 2006, 8, 135.

22. Burgess, K. Henderson, I. Tetrahedron Lett. 1990, 31, 6949.

23. (a) Burgess, K.; Chaplin, D. A.; Henderson, I.; Pan, Y. T.; Elbein, A. D. J. Org. Chem. 1992, 57, 1103. (b) Burgess, K.; Chaplin, D. A. Tetrahedron Lett. 1992, 33, 6077.

24. Duan, J. J. W.; Smith, A. B. J. Org. Chem. 1993, 58, 3703.

25. (a) Bartlett, P. A.; Meadow, J. D.; Brown, E. G.; Morimoto, A.; Jernstedt, K. K. J. Org. Chem. 1982, 47, 4013. (b) Cardillo, G.; Orena, M.; Porei, G.; Sandri, S. J. Chem. Soc. Chem. Commun. 1981, 465. (c) Bo, A.; Cardillo, G.; Orena, M.; Porzi, G.; Sandri, S. J. Org. Chem. 1982, 47, 4626.

26. Jadhav, P. K.; Woerner, F. J. Tetrahedron Lett. 1994, 35, 8973.

27. (a) Rhinehart. B. L.; Robinson, K. M.; Payne, A. J.; Wheatley, M. E.; Fisher, J. L.; Liu. P. S.; Cheng, W. Life. Sci. 1987, 41, 2325. (b) Trugnan, G.; Rousset, M.; Zweibaum, A. Febs. Lett. 1966, 195, 28. (c) Humphreys, M. J.; Matsumoto, K.; White, S. L.; Olden, K. Cancer Res. 1986, 46, 5215. (d) Sunkara, P. S.; Bowlin, T. L.; Liu, P. S.; Sjoerdsma, A. Biochem. Biophys. Res. Commun. 1987, 148, 206. (e) Tyms, A. S.; Berrie. E. M.; Ryder, T. A.; Nash, R. J.; Hagarty, M. P.; Taylor, D. L.; Moberley, M. A.; Davis, J. M.; Bell, E. A.; Jeffries, D. J.; Taylor-Robinson, D.; Fellows, L. E. Lancet 1987, ii, 1026. (f) Gruters, R. A.; Neefjes, J. J.; Tersmette, M.; de Coede, R. E. Y.; Tulp. A.; Huisman, H. G.; Miedema, F.; Ploegh, H. L. Nature 1987, 330, 74. (g) Walker, B. D.; Kawalski, M.; Goh, W. C.; Kozarsky, K.; Krieger, M.; Rosen, C.; Rohrschneider, L.; Haseltine, W. A.; Sodroski, J. Proc. Nat. Acad. Sci. U.S.A., 1987, 84, 8120. 
28. Jadhav, P. K.; Man, H. W. Tetrahedron Lett. 1996, 37, 1153.

29. Sutherlin, D. P.; Armstrong, R. W. J. Org. Chem. 1997, 62, 5267.

30. (a) Coleman, R. S.; Kong, J. S. J. Am. Chem. Soc. 1998, 120, 3538. (b) Coleman, R. S.; Kong, J. S.; Richardson, T. E. J. Am. Chem. Soc. 1999, 121, 9088. (c) Coleman, R. S.; Li, J.; Navarro, A. Angew. Chem. Int. Ed. 2001, 40, 1736.

31. Barrett, A. G. M.; Bennett, A. J.; Menzer, S.; Smith, M. L.; White, A. J. P.; Williams, D. J. J. Org. Chem. 1999, 64, 162.

32. Ahmed, M.; Barrett, A. G. M.; Beall, J. C.; Braddock, D. C.; Flack, K.; Gibson, V. C.; Procopiou, P. A.; Salter, M. M. Tetrahedron 1999, 55, 3219.

33. Barrett, A. G. M.; Beall, J. C.; Braddock, D. C.; Flack, K.; Gibson, V. C.; Salter, M. M. J. Org. Chem. 2000, 65, 6508.

34. Smith, A. B.; Friestad, G. K.; Barbosa, J.; Bertounesque, E.; Hull, K. G.; Iwashima, M.; Qiu, Y.; Salvatore, B. A.; Spoors, P. G.; Duan, J. J. W. J. Am. Chem. Soc. 1999, 121, 10468.

35. Wang, X.; Porco, J. A. J. Am. Chem. Soc. 2003, 125, 6040.

36. (a) Beumer, R.; Bayon, P.; Bugada, P.; Ducki, S.; Mongelli,N.; Sirtori, F. R.; Telser, J.; Gennari, C. Tetrahedron Lett. 2003, 44, 681. (b) Beumer, R.; Bayon, P.; Bugada, P.; Ducki, S.; Mongelli,N.; Sirtori, F. R.; Telser, J.; Gennari, C. Tetrahedron 2003, 59, 8803. (c) Castoldi, D.; Caggiano, L.; Bayon, P.; Costa, A. M.; Cappella, P.; Sharon, O.; Gennari, C. Tetrahedron 2005, 61, 2123. (d) Castoldi, D.; Caggiano, L.; Panigada, L.; Sharon, O.; Costa, A. M.; Gennari, C. Chem. Eur. J. 2006, 12, 51.

37. Liao, X.; Wu, Y.; deBrabander, J. K. Angew. Chem. Int. Ed. 2003, 42, 1648.

38. Liu, B.; Zhou, W. S. Org. Lett. 2004, 6, 71.

39. Yin, N.; Wang, G.; Qian, M.; Negishi, E. I. Angew. Chem. Int. Ed. 2006, 45, 2916.

40. (a) Smith, A. L.; Hwang, C. K.; Pitsinos, E. N.; Scarlato, G. R.; Nicolaou, K. C. J. Am. Chem. Soc. 1992, 114, 3134. (b) Smith, A. L.; Pitsinos, E. N.; Hwang, C. K.; Mizuno, Y.; Saimoto, H.; Scarlato, G. R.; Suzuki, T.; Nicolaou, K. C. J. Am. Chem. Soc. 1993, 115, 7612.

41. Ramachandran, P. V.; Chandra, J. S.; Reddy, M. V. R. J. Org. Chem. 2002, 67, 7547.

42. (a) Ramachandran, P. V.; Prabhudas, B.; Pratihar, D.; Chandra, J. S.; Reddy, M. V. R. Tetrahedron Lett. 2003, 44, 3745. (b) Ramachandran, P. V.; Prabhudas, B.; Chandra, J. S.; Reddy, M. V. R.; Brown, H. C. Tetrahedron Lett. 2004, 45, 1011. (c) Ramachandran, P. V.; Chandra, J. S.; Prabhudas, B.; Pratihar, D.; Reddy, M. V. R. Org. Biomol. Chem. 2005, 3, 3812.

43. Ramachandran, P. V.; Prabhudas, B.; Chandra, J. S.; Reddy, M. V. R. J. Org. Chem. 2004, 69, 6294.

44. Ramachandran, P. V.; Liu, H.; Reddy, M. V. R.; Brown, H. C. Org. Lett. 2003, 5, 3755.

45. Ramachandran, P. V.; Padiya, K. J.; Rauniyar, V.; Reddy, M. V. R.; Brown, H. C. J. Fluor. Chem. 2004, 125, 615. (b) Ramachandran, P. V.; Padiya, K. J.; Rauniyar, V.; Reddy, M. V. R.; Brown, H. C. Tetrahedron Lett. 2004, 45, 1015. 
46. Ramachandran, P. V.; Padiya, K. J.; Reddy, M. V. R.; Brown, H. C. J. Fluor. Chem. 2004, 125,579 .

47. (a) Overman, L. E. J. Am. Chem. Soc. 1974, 96, 597. (b) Review: Overman, L. E. Acc. Chem. Res. 1980, 13, 218.

48. Ramachandran, P. V.; Burghardt, T. E.; Berry, L. B. J. Org. Chem. 2005, 70, 2329.

49. (a) Zhang, Q.; Lu, H.; Richard, C.; Curran, D. P. J. Am. Chem. Soc. 2004, 126, 36. (b) Curran, D. P.; Zhang, Q.; Richard, C.; Lu, H.; Gudipati, V.; Wilcox, C. J. Am. Chem. Soc. 2006, $128,9561$.

50. Curran, D. P.; Furukawa, T. Org. Lett. 2002, 4, 2233.

51. (a) Barrett, A. G. M.; Edmunds, J. J.; Horita, K.; Parkinson, C. J.; J. Chem. Soc. Chem.Commun. 1992, 1236. (b) Anderson, O. P.; Barrett, A. G. M.; Edmunds, J. J.; Hachiya, S. I.; Hendrix, J. A.; Horita, K.; Malecha, J. W.; Parkinson, C. J.; VanSickle, A. Can. J. Chem. 2001, 79, 1562.

52. Roush, W. R.; Follows, B. C. Tetrahedron Lett. 1994, 35, 4935.

53. Bratz, M.; Bullock, W. H.; Overman, L. E.; Takemoto, T. J. Am. Chem. Soc. 1995, 117, 5958.

54. (a) Castoldi, D.; Caggiano, L.; Panigada, L.; Sharon, O.; Costa, A. M.; Gennari, C. Angew. Chem. Int. Ed. 2005, 44, 588. (b) reference 8c.

55. Sutherlin, D. P.; Armstrong, R. W. Tetrahedron Lett. 1993, 34, 4897.

56. Ganesh, P.; Nichols, K. M. J. Org. Chem. 1997, 62, 1737.

57. Hoffmann, R. W.; Kemper, B.; Metternich, R.; Lehmeier,T. Liebigs Ann. Chem. 1985, 2246.

\section{Authors' biographical data}

\section{J. Subash Chandra}

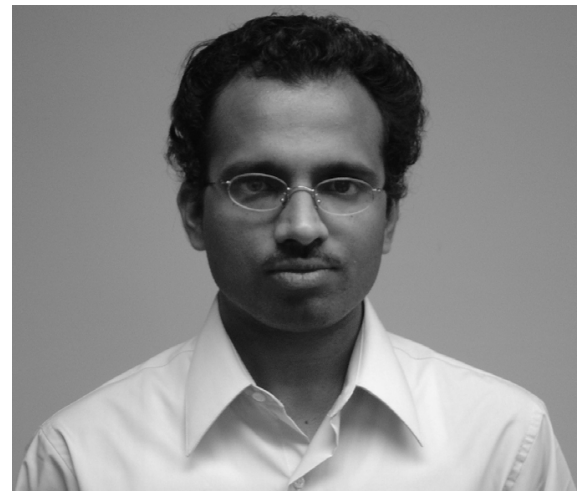

Subash, born in 1978 in Calcutta, India, received his Bachelor of Science degree in Chemistry in 1998 from Pondicherry University, India. He then completed his Masters in Chemistry from the 
University of Hyderabad, India. He started his Ph.D. at the Herbert C. Brown Center for Borane Research, Department of Chemistry, Purdue University as an International Graduate Scholar in Fall 2000. After completing his Ph.D. in Summer 2005, he worked at the University of Pennsylvania as a post-doctoral research assistant from Fall 2005 to Summer 2006. He is currently working with Professor M. Venkat Ram Reddy at the Department of Chemistry and Biochemistry, University of Minnesota Duluth.

\section{Venkat Ram Reddy}

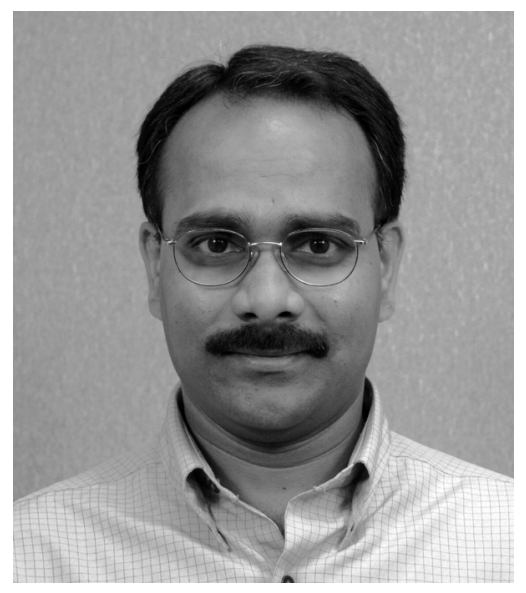

M. Venkat Ram Reddy, born in 1967, received his Ph.D. in organic chemistry under the supervision of Professor Y. D. Vankar from the Indian Institute of Technology, Kanpur, India. Later, he worked with Nobel Laureate Professor Herbert C. Brown and Professor P. V. Ramachandran at the Department of Chemistry, Purdue University for his post-doctoral studies. He was then appointed as the Assistant Research Scientist in the newly established Herbert C. Brown Center for Borane Research, Purdue University. Since the summer of 2004, he has been an Assistant Professor at University of Minnesota Duluth. He has co-authored more than 50 publications and three patents. His research interests include asymmetric organic synthesis and synthesis of small molecules as anticancer agents. 